\title{
THE INTAKE OF SELECTED MINERALS AND TRACE ELEMENTS IN EUROPEAN COUNTRIES
}

\section{COMPILED AND EDITED BY W. VAN DOKKUM}

TNO-Nutrition and Food Research, Zeist, The Netherlands (for members* of FLAIR Concerted Action No. 10: The measurement of micronutrient absorption and status)

\section{CONTENTS}

INTRODUCTION . . . . . . . . . . . . . . . 272

BELGIUM (H. Deelstra) . . . . . . . . . . . . . . . 273

INTAKE DATA FOR MANGANESE . . . . . . . . . . . . . . . 273

INTAKE DATA FOR SELENIUM . . . . . . . . . . . . . . . . 273

INTAKE DATA FOR COPPER AND ZINC . . . . . . . . . . . 273

INTAKE DATA FOR CALCIUM AND MAGNESIUM . . . . . . . . . . 273

INTAKE DATA FOR CADMIUM, LEAD AND MERCURY . . . . . . 275

DENMARK (S. Højbjerg, M. Hansen and B. Sandström) . . . . . . . . . . 275

FRANCE (M. Lamand). . . . . . . . . . . . . . . . 276

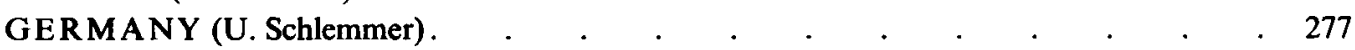

GREAT BRITAIN (S. Lee, D. Buss and H. M. Crews) . . . . . . . . . 280

NATIONAL FOOD SURVEY $. \quad . \quad . \quad . \quad . \quad . \quad . \quad . \quad . \quad . \quad . \quad . \quad 280$

TOTAL DIET STUDY

DIETARY SURVEY OF INDIVIDUALS . . . . . . . . . . . . . . . 281

Adults . . . . . . . . . . . . . . . . . . . 281

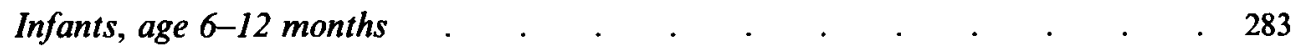

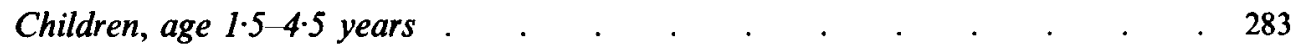

Schoolchildren . . . . . . . . . . . . . . . . . . . 284

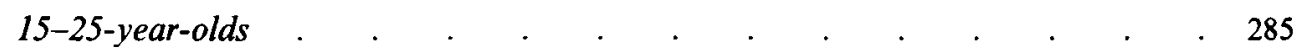

IRELAND (REPUBLIC AND NORTHERN IRELAND) (K. Cashman and A.

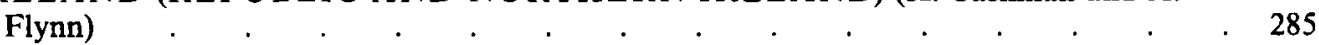

MINERAL INTAKE DATA FOR THE REPUBLIC OF IRELAND . . . . . 285

MINERAL INTAKE DATA FOR NORTHERN IRELAND . . . . . . . 285

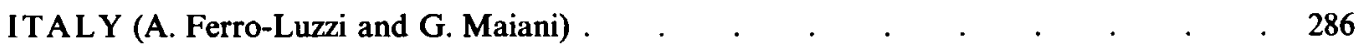

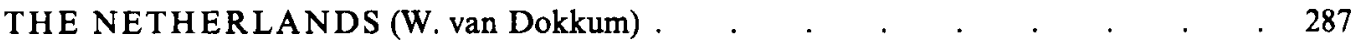

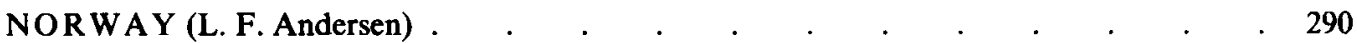

CALCIUM, IRON AND MAGNESIUM INTAKES AMONG 13- AND 18-YEAR-
OLD MALES AND FEMALES. . . . . . . . . . . . . 290

CALCIUM, IRON AND MAGNESIUM INTAKES AMONG 75-76-YEAR-OLD

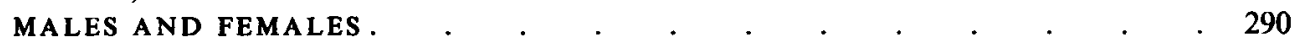

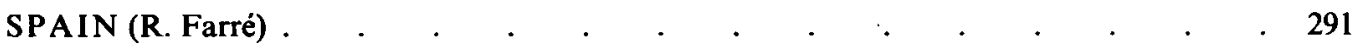

ELEMENT INTAKE DATA IN FOUR SPANISH AREAS . . . . . . . . 291

* A list of contributors and their affiliations is given on p. 302. 
ELEMENT INTAKE FROM A NATIONAL (SPANiSh) TOTAL DIET . . . . 291

ESTIMATED INTAKE OF ELEMENTS IN BASQUE COUNTRY . . . . . . 292

ESTIMATED INTAKE OF TRACE ELEMENTS IN TARRAGONA PROVINCE . . 293

ESTIMATED INTAKE OF TRACE ELEMENTS IN VALENCIA . . . . . . . 294

SWEDEN (S. Højbjerg, M. Hansen and B. Sandström) . . . . . . . . . . . 295

SWITZERLAND (D. Barclay) . . . . . . . . . . . . . . . . 295

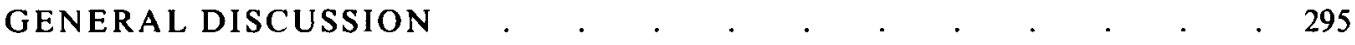

REFERENCES . . . . . . . . . . . . . . . . . . . . . 299

\section{INTRODUCTION}

To conduct a proper evaluation of 'element status' among population groups (in a broad sense), the following information is required.

It should be known whether the intake of elements among various population groups is safe and adequate. To this end, intake data for essential elements should be compared with the Recommended Dietary Allowances (RDA) which have been established for defined population groups. For toxic elements the intake is evaluated by comparison with the Acceptable Daily Intake (ADI).

It should be known whether low intakes of the nutrient elements are reflected by a low element body status with respect to these elements. Unfortunately, reference data are only available for a limited number of elements. In the evaluation of element status, the bioavailability of the elements should also be taken into account.

When a low status has been observed for particular elements, it is relevant to ask whether this affects (functional) performance.

During the various meetings within FLAIR Concerted Action No. 10, intake data were not considered in any detail. It was therefore agreed during a meeting in Germany (May 1993) that intake data for a number of minerals and trace elements among population groups in the European Union (EU) and other European countries would be collected. The elements to be included in this survey, based on data from previous studies, included calcium, magnesium, iron, zinc, copper, manganese, iodine, selenium, chromium, lead, mercury and cadmium. All countries participating in the FLAIR Concerted Action No 10 were requested to collect data on intake, indicating methods, defining population groups and reporting data on the percentage contribution of specific food groups to the daily intake of the elements, where this information was available.

As could have been predicted, the information received from the various countries was not uniform. We have summarized the element intake data from each country separately in the following sections. This is followed by a short discussion of the reported intake data, from which some general conclusions are drawn. For evaluating the intake of toxic elements the Joint Expert Committee of the WHO/FAO has recommended the use of Provisional Tolerable Weekly Intakes (PTWI). Although not strictly rigorous the PTWI has been 'translated' into an unofficial Provisional Tolerable Daily Intake (PTDI) in order to evaluate the measured or calculated daily intake.

For essential elements, safe and adequate levels of intake and other recommendations have been established. Although the use of these recommendations for evaluating diets is debatable they have been tabulated in order to at least gain an impression of the adequacy of the intake of essential elements. Some additional comments are presented regarding the use of RDA in the discussion section at the end of this paper. 


\section{BELGIUM}

\section{INTAKE DATA FOR MANGANESE}

The daily dietary intake of $\mathrm{Mn}$ by different population groups in Belgium was estimated by a duplicate portion study (Robberecht et al. 1994b; Stobbaerts et al. 1991, 1995). Duplicate diets were collected from a normal family at the University Hospital of Antwerp, in a residential home for elderly people and from vegetarians and macrobiotics. Moreover, duplicate diets were collected in four different places (restaurants of hospitals and military places) during 7 consecutive days. In the homogenized diet samples Mn was analysed by flameless atomic absorption spectrometry (Table 1).

For Mn no RDA has been established; the (US) estimated safe and adequate intake of $\mathrm{Mn}$ for adults is $2 \cdot 0-5 \cdot 0 \mathrm{mg} / \mathrm{d}$ (Food and Nutrition Board, 1989). Most reported intake data on $\mathrm{Mn}$ in the Belgian study fall within this range. The $\mathrm{Mn}$ intake by macrobiotics is higher, partly owing to the relatively high concentration of $\mathrm{Mn}$ in cereals. The conclusion is that the daily requirements for $\mathrm{Mn}$ are met by normal food habits in Belgium.

\section{INTAKE DATA FOR SELENIUM}

Estimates of the dietary Se intake in different population groups in Belgium are summarized in Table 2. Both duplicate diet analysis and dietary consumption data were used for calculating the daily intake of Se (Robberecht \& Deelstra, 1984; Roekens et al. 1985, 1986; Robberecht et al. 1994a).

The (US) Food and Nutrition Board (1989) has established an RDA for Se of $55 \mu \mathrm{g} / \mathrm{d}$ for female adults and of $70 \mu \mathrm{g} / \mathrm{d}$ for male adults. The United Kingdom Dietary Reference Values (Department of Health, 1991) for Se are $75 \mu \mathrm{g} / \mathrm{d}$ for male adults and $60 \mu \mathrm{g} / \mathrm{d}$ for female adults.

The overall conclusion is that the Se intake in Belgium is at the lower level of the recommendations. For formula diets fed to infants the Se intake is also low compared to the recommendations of $10 \mu \mathrm{g} / \mathrm{d}$. For adults, the food group 'meat' contributes mostly to the daily Se intake (c. 40\%), followed by the groups 'bread' (c. 22\%) and 'fish' (c. 12\%).

\section{INTAKE DATA FOR COPPER AND ZINC}

Duplicate diets of several population groups in Belgium (in the region of Antwerp) were analysed for $\mathrm{Cu}$ and $\mathrm{Zn}$ by atomic absorption spectrometry (Swerts et al. 1993; Van Cauwenbergh et al. 1995; Table 3).

It is concluded that in various cases $\mathrm{Cu}$ and $\mathrm{Zn}$ daily intakes are below the (USA) recommendations of $1.5-3.0 \mathrm{mg} / \mathrm{d}$ for $\mathrm{Cu}$ and $12-15 \mathrm{mg} / \mathrm{d}$ for $\mathrm{Zn}$ for adults. If the UK Dietary Reference Values (DRV) are taken into account $(1.2 \mathrm{mg} /$ day for $\mathrm{Cu}$ and $7 \cdot 0-9.5 \mathrm{mg} / \mathrm{d}$ for $\mathrm{Zn}$ ), the measured intake levels of $\mathrm{Cu}$ can be evaluated as reasonable (apart from vegetarians); for $\mathrm{Zn}$ the intake is lower than the DRV.

\section{INTAKE DATA FOR CALCIUM AND MAGNESIUM}

In four different places $24 \mathrm{~h}$ duplicate diets were collected during 7 consecutive days (Hendrix et al. 1995) as described for $\mathrm{Mn}, \mathrm{Se}$ and $\mathrm{Cu}$ in the previous paragraphs (Table 4).

The overall mean intake for $\mathrm{Ca}(618 \mathrm{mg} / \mathrm{d})$ is lower than the US RDA for adults (Buchet et al. 1981); for $\mathrm{Mg}$ the overall mean intake is $271 \mathrm{mg} / \mathrm{d}$, which is below the (US) 
Table 1. Manganese intake by different population groups in Belgium

\begin{tabular}{lc}
\hline Population group & Intake $(\mathrm{mg} / \mathrm{d})$ and (SD) \\
\hline Hospital meal $(7 \mathrm{~d})$ & $2 \cdot 5(0 \cdot 3)$ \\
Home meal $(n=4,7 \mathrm{~d})$ & $3 \cdot 6(0 \cdot 9)$ \\
Elderly people $(2$ homes, $7 \mathrm{~d})$ & $2 \cdot 1(0 \cdot 6)$ \\
Vegetarians $(n=3,4 \mathrm{~d})$ & $2 \cdot 9(2 \cdot 0)$ \\
Macrobiotics $(n=3,2-3 \mathrm{~d})$ & $6 \cdot 7(3 \cdot 6)$ \\
Royal Military Academy (Brussels) $(7 \mathrm{~d})$ & $3 \cdot 8(1 \cdot 1)$ \\
University Hospital (Antwerp) $(7 \mathrm{~d})$ & $3 \cdot 4(1 \cdot 1)$ \\
Military Service Quarter (Vilvoorde) $(7 \mathrm{~d})$ & $3 \cdot 1(1 \cdot 0)$ \\
University Hospital (Liège) (7d) & $2 \cdot 1(0 \cdot 2)$ \\
\hline
\end{tabular}

Table 2. Selenium intake by different population groups in Belgium

\begin{tabular}{llc}
\hline Population group & \multicolumn{1}{c}{ Method } & Intake $(\mu \mathrm{g} / \mathrm{d})$ and (SD) \\
\hline Total population & Consumption statistics & 55 \\
South-east Belgium & Dietary record & 41 \\
North-west Belgium & Dietary record & 45 \\
Restaurant in hospital (Antwerp) $(n=6)$ & 24 h duplicate diet & $52(16)$ \\
Macrobiotics $(n=9)$ & 24 h duplicate diet & $34(16)$ \\
Vegetarians $(n=12)$ & 24 h duplicate diet & $13(9)$ \\
Elderly people $(n=14)$ & 24 h duplicate diet & $42(11)$ \\
l-6 months infants & Analysis of infant formula diets & $3.0-7.8$ \\
Royal Military Academy (Brussels) & 24 h duplicate diet over 7 d & $47(13)$ \\
University Hospital (Antwerp) & 24 h duplicate diet over 7 d \\
Military Service Quarter (Vilvoorde) & 24 h duplicate diet over 7 d & $45(17)$ \\
University Hospital (Liege) & 24 h duplicate diet over 7 d & $61(20)$ \\
\hline
\end{tabular}

Table 3. Copper and zinc intakes by different population groups in Belgium

\begin{tabular}{|c|c|c|}
\hline Population group & Method & Intake $(\mathrm{mg} / \mathrm{d})$ and $(\mathrm{SD})$ \\
\hline Macrobiotics $(n=3)$ & $24 \mathrm{~h}$ duplicate diet over $2-3 \mathrm{~d}$ & $\begin{array}{l}\text { Cu 1.5 (0.4) } \\
\text { Zn } 7.0(1.9)\end{array}$ \\
\hline Vegetarians $(n=3)$ & $24 \mathrm{~h}$ duplicate diet over $4 \mathrm{~d}$ & $\begin{array}{l}\text { Cu } 0.8(0.3) \\
\text { Zn } 3.9(2.2)\end{array}$ \\
\hline Elderly people & Duplicate diet in 2 homes & $\begin{array}{l}\text { Cu } 1 \cdot 1(0 \cdot 2) \\
\operatorname{Zn~} 6 \cdot 4(1 \cdot 7)\end{array}$ \\
\hline Royal Military Academy (Brussels) & 24 h duplicate diet over $7 \mathrm{~d}$ & Cu $1.7(0.5)$ \\
\hline University Hospital (Antwerp) & $24 \mathrm{~h}$ duplicate diet over $7 \mathrm{~d}$ & $\mathrm{Cu} 1.5(0.3)$ \\
\hline Military Service Quarter (Vilvoorde) & $24 \mathrm{~h}$ duplicate diet over $7 \mathrm{~d}$ & $\mathrm{Cu} 1.8(0.8)$ \\
\hline University Hospital (Liège) & $24 \mathrm{~h}$ duplicate diet over $7 \mathrm{~d}$ & $\operatorname{Cu~} 0.9(0.1)$ \\
\hline
\end{tabular}

recommendations for male adults, but close to the recommendations for females. When compared with the UK DRV, the intake of $\mathrm{Ca}$ is close to the DRV ( $700 \mathrm{mg} / \mathrm{d}$ for adults) and the intake of $\mathrm{Mg}$ meets the DRV $(300 \mathrm{mg} / \mathrm{d}$ for male adults and $270 \mathrm{mg} / \mathrm{d}$ for female adults) in two cases (Table 4). 
Table 4. Calcium and magnesium intakes in different places in Belgium

\begin{tabular}{lcc}
\hline \hline Location & \multicolumn{1}{c}{ Method } & $\overline{\text { Intake (mg/d) and (sD) }}$ \\
\hline Royal Military Academy (Brussels) & 24 h duplicate diet over 7d & $\mathrm{Ca} \mathrm{674(263)}$ \\
University Hospital (Antwerp) & $24 \mathrm{~h}$ duplicate diet over 7d & $\mathrm{Mg} \mathrm{307} \mathrm{(52)}$ \\
Military Service Quarter (Vilvoorde) & $24 \mathrm{~h}$ duplicate diet over 7 d & $\mathrm{Ca} 701(182)$ \\
University Hospital (Liège) & 24 h duplicate diet over 7d & $\mathrm{Ca} \mathrm{665(306)}$ \\
& & $\mathrm{Mg} \mathrm{306} \mathrm{(43)}$ \\
& & $\mathrm{Ca} \mathrm{432} \mathrm{(78)}$ \\
& & $\mathrm{Mg} 214(11)$ \\
\hline \hline
\end{tabular}

\section{INTAKE DATA FOR CADMIUM, LEAD AND MERCURY}

One hundred and twenty four daily meals were collected in three areas of Belgium (Buchet et al. 1981). The following median values were found: $\mathrm{Cd} 15 \mu \mathrm{g} / \mathrm{d}, \mathrm{Pb} 96 \mu \mathrm{g} / \mathrm{d}$ and $\mathrm{Hg}$ $6.5 \mu \mathrm{g} / \mathrm{d}$. The distribution of the individual results suggests that about $1-2 \%$ of the $\mathrm{Hg}$ and $\mathrm{Cd}$ oral intake and $8 \%$ of the $\mathrm{Pb}$ daily intake exceed the tolerable level proposed by the World Health Organization.

\section{DENMARK}

From the data submitted, two studies are represented in this review. The first covers the intake of essential and toxic trace elements in a random sample of Danish men (30-34 years of age) in which 100 duplicate diets $(48 \mathrm{~h}$ ) were analysed (Bro et al. 1990). In this survey observed $\mathrm{N}, \mathrm{Na}$ and $\mathrm{K}$ intakes were approximately $25 \%$ lower than total daily excretion (24 $\mathrm{h}$ urine). It is therefore assumed that dietary intakes of nutrients during the duplicate portion sampling period were reduced by $25 \%$. Thus the observed levels can be considered minimum estimates of habitual intake.

The second study comprises a calculation of the intake of some essential trace elements based on data from 2242 28-d dietary histories (Haraldsdóttir et al. 1986). Food models were used for estimating portion sizes (Tables 5 and 6).

Intakes of I for men and women are considerably lower than the Nordic Nutrition Recommendations (Nordic Committee on Foods, 1989). Many people have a high

Table 5. Dietary intakes of some toxic and essential trace elements among 30-34-year-old males in Denmark calculated from duplicate diet analyses

\begin{tabular}{ll}
\hline \hline & $\begin{array}{c}\text { Mean intake per week and (sD) } \\
\text { Trace element }\end{array}$ \\
\hline $\mathrm{Hg}(\mu \mathrm{g})$ & $26(80)$ (maximum 769$)\left[43^{*}\right]$ \\
$\mathrm{Pb}(\mu \mathrm{g})$ & $7(148)$ (maximum 957$)\left[430^{*}\right]$ \\
$\mathrm{Cd}(\mu \mathrm{g})$ & $15(14)($ maximum 102$)\left[60^{*}\right]$ \\
$\mathrm{Fe}(\mathrm{mg})$ & $11 \cdot 9(4 \cdot 3)[10 \mathrm{M} / 18 \mathrm{~F}]$ \\
$\mathrm{Zn}(\mathrm{mg})$ & $11 \cdot 7(4 \cdot 0)[12]$ \\
$\mathrm{Cu}(\mathrm{mg})$ & $1 \cdot 2(0 \cdot 6)[2-2 \cdot 5]$ \\
$\mathrm{Se}(\mu \mathrm{g})$ & $56(28)[50]$ \\
$\mathrm{Mn}(\mathrm{mg})$ & $4 \cdot 5(2 \cdot 2)[2 \cdot 5-5]$ \\
\hline
\end{tabular}

- PTDI, Provisional Tolerable Daily Intake as calculated from the WHO/FAO Provisional Tolerable Weekly Intake for a person with a body weight of $60 \mathrm{~kg}$. 
Table 6. Dietary intake of some essential minerals and trace elements among the Danish population of 15-80 years of age calculated from 28 -d dietary histories $(n=2242)$

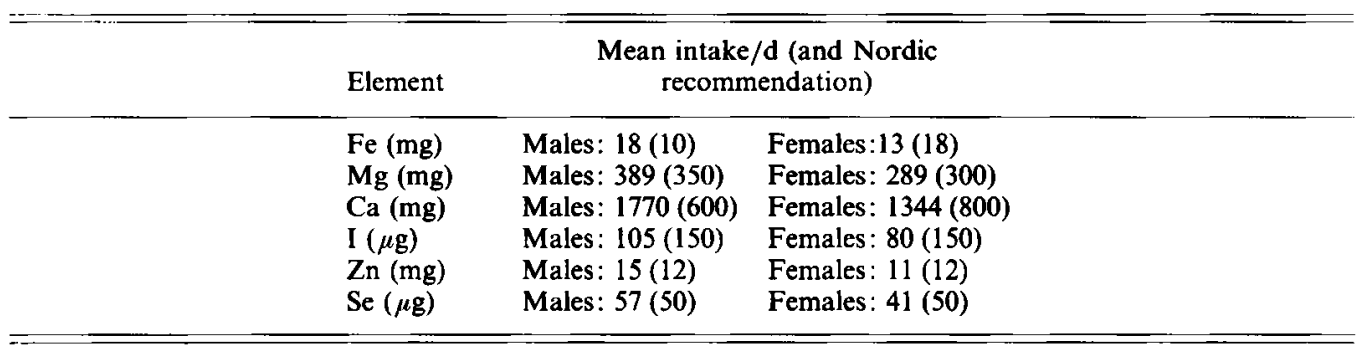

probability of intake below their need. Intake of $\mathrm{Fe}$ (particularly in menstruating women) is also low. Comparing the data with recommendations, it seems that many women do not fulfil their needs. Approximately $50 \%$ of the men have intakes twice the recommendations. Regarding the distribution of $\mathrm{Mg}$ intake, those at the lower end may have too low an intake to fulfil needs. Typical $\mathrm{Ca}$ intake is high; approximately $99 \%$ of the population receive more than the recommendations (men have a particularl high intake). However, Ca requirement is currently being debated in Denmark.

The food groups that contribute most to the reported intakes are: for $\mathrm{Mg}$, cereals $(27 \%$ contribution to the daily intake), milk (14\%) and vegetables (14\%). For $\mathrm{Ca}$ the food groups are cereals $(30 \%)$, milk $(29 \%)$ and cheese $(24 \%)$. For I, the most important food groups are milk ( $27 \%$ contribution), fish $(16 \%)$ and eggs $(10 \%)$. For $\mathrm{Fe}$ the food groups with a significant contribution include cereals $(50 \%)$, meat $(19 \%)$ and vegetables $(12 \%)$.

\section{FRANCE}

Four hundred different food items were analysed for a number of essential minerals and trace elements. For the calculation of mineral intake, the foods were grouped into 10 major categories: vegetables, fruits, starchy foods, meat, fish, milk, cheese, yogurt, eggs and beverages (Lamand et al. 1994). Food intake data were obtained from the publications of the Institut National de la Statistique et des Etudes Economiques. This Institute publishes a list of all foods purchased by French households. Family food intake was calculated according to the age of the head of the family. All data in this publication refer to the average person in the family. Meals eaten outside the home were taken into account. Adjustments were made for losses due to peeling and cleaning. Daily element intake data were obtained after adjustment for energy intake, for which an optimum energy level was the basis (Table 7).

Comparing these results to the French RDA (Favier \& Lamand, 1992) it is concluded that the intake of $\mathrm{P}$ and $\mathrm{Ca}$ for men and women and the $\mathrm{Fe}$ intake for men were adequate. The intakes of $\mathrm{Mg}, \mathrm{Cu}$ and $\mathrm{Mn}$ were between 80 and $100 \%$ of the RDA. Intake levels of $\mathrm{Zn}$, I and Se were $50-80 \%$ of the RDA. The Fe intake calculated for women is considered to be seriously deficient and the low Se intake in men may induce real biochemical subdeficiencies with clinical consequences.

Important sources of daily element intake are: $\mathrm{Ca}$, mainly milk and milk products; $\mathrm{P}$, milk and milk products, starchy foods and meat and meat products; $\mathrm{Mg}$, starchy foods, fruits/vegetables and milk and milk products; $\mathrm{Fe}$, starchy foods, meat and meat products and fruits/vegetables; $\mathrm{Cu}$, starchy foods and fruits/vegetables; $\mathrm{Zn}$, meat and meat products, milk and milk products and starchy foods; Mn, starchy foods and fruits/ 
Table 7. Daily intake of essential minerals and trace elements for adult consumers receiving an optimal energy intake

\begin{tabular}{|c|c|c|c|c|c|c|c|c|c|}
\hline Group & $\underset{(\mathrm{mg} / \mathrm{d})}{\mathrm{Ca}}$ & $\begin{array}{c}\mathrm{P} \\
(\mathrm{mg} / \mathrm{d})\end{array}$ & $\underset{(\mathrm{mg} / \mathrm{d})}{\mathrm{Mg}}$ & $\underset{(\mathrm{mg} / \mathrm{d})}{\mathrm{Fe}}$ & $\underset{(\mathrm{mg} / \mathrm{d})}{\mathrm{Cu}}$ & $\underset{(\mathrm{mg} / \mathrm{d})}{\mathrm{Zn}}$ & $\underset{(\mathrm{mg} / \mathrm{d})}{\mathrm{Mn}}$ & $\begin{array}{c}\mathrm{I} \\
(\mu \mathrm{g} / \mathrm{d})\end{array}$ & $\begin{array}{c}\mathrm{Se} \\
(\mu \mathrm{g} / \mathrm{d})\end{array}$ \\
\hline $\begin{array}{l}\text { Men } 25-60 \text { years } \\
2700 \mathrm{kcal}\end{array}$ & 1026 & 1304 & 324 & 10 & $1 \cdot 3$ & $11 \cdot 7$ & $2 \cdot 1$ & 109 & 43 \\
\hline $\begin{array}{l}\text { Women } 25-60 \text { years } \\
2200 \mathrm{kcal}\end{array}$ & 836 & 1063 & 264 & $8 \cdot 1$ & $1 \cdot 1$ & $9 \cdot 6$ & 1.7 & 89 & 35 \\
\hline $\begin{array}{l}\text { Men }>60 \text { years } \\
2300 \mathrm{kcal}\end{array}$ & 743 & 1005 & 264 & 8.5 & 1.2 & $10-0$ & $2 \cdot 0$ & 80 & 34 \\
\hline $\begin{array}{l}\text { Women }>60 \text { years } \\
1950 \mathrm{kcal}\end{array}$ & 630 & 852 & 224 & 7.2 & $1 \cdot 0$ & 8.5 & 1.7 & 68 & 29 \\
\hline
\end{tabular}

vegetables; I, milk and milk products, starchy foods and eggs; Se, meat and meat products, milk and milk products, eggs and fish.

Although eggs have a high mineral content, they are consumed in too low quantities to be an important mineral source. The same holds true for the intake of I and Se from fish.

\section{GERMANY}

The National German Food Consumption Survey (Nationale Verzehrsstudie; Frank, 1991) assessed food consumption in the Federal Republic of Germany in the years 1985-8. In 1987-8, on the basis of a representative sample of this survey (VERA-Study), the daily dietary intake of trace elements and minerals in adults ( $>18$ years of age; $n=2006$ ) was calculated by using 7-day protocols and the food table of 'Bundeslebensmittelschlüssel' (Heseker et al. 1992).

The daily intakes of $\mathrm{Ca}, \mathrm{Mg}, \mathrm{Fe}, \mathrm{Zn}, \mathrm{Cu}$ and $\mathrm{I}$ for women and men are summarized in Table 8 (Heseker et al. 1992). As the intake data did not display a normal distribution, medians rather than the mean values were used. To assess the status, biomarkers such as serum concentration of $\mathrm{Cu}, \mathrm{Zn}, \mathrm{Mg}$ and $\mathrm{Se}$, and urine excretion/24 $\mathrm{h}$ for $\mathrm{Ca}$ and $\mathrm{I}$ were determined. The data were compared with information obtained from reference groups of the VERA-Study, showing an optimal supply of these trace elements and minerals (Table 9; DGE, 1992; Kübler et al. unpublished). The contribution of various food groups to the daily intake of trace elements and minerals is documented in Table 10 (Kübler $e t$ al. unpublished). Table 11 shows the weekly intake of toxic trace elements (DGE, 1988) compared with the PTWI recommended by the WHO.

Evaluation of the intake data (Table 8) and of the biomarkers of status show that, in general, the German population is quite well supplied with $\mathrm{Mg}, \mathrm{Cu}, \mathrm{Zn}$ and probably Se (DGE, 1992). For Mg the intake data (Table 8) meet the RDA values of $300 \mathrm{mg} / \mathrm{d}$ for women and $350 \mathrm{mg} / \mathrm{d}$ for men. The serum levels of $\mathrm{Mg}$ are slightly higher than the reference values (Table 9), indicating an adequate $\mathrm{Mg}$ supply. The intake of $\mathrm{Cu}$ and $\mathrm{Zn}$ (Table 8 ) is lower than the RDA (2-3 and $15 \mathrm{mg} / \mathrm{d}$ respectively); however this does not result in a lower serum level for these two elements (Table 9). This indicates that the supply of $\mathrm{Cu}$ and $\mathrm{Zn}$ is also adequate, although it is debatable whether serum levels are sensitive biomarkers for the assessment of $\mathrm{Zn}$ and $\mathrm{Cu}$ status. The situation for $\mathrm{Fe}$ is different. For men, the intake $(\sim 14 \mathrm{mg} / \mathrm{d}$; Table 8$)$, is higher than the RDA of $10 \mathrm{mg} / \mathrm{d}$. For young women, however, the intake $(\sim 12 \mathrm{mg} / \mathrm{d}$; Table 8$)$ is lower than the RDA of $18 \mathrm{mg} / \mathrm{d}$. Moreover, in young women the serum ferritin level, which is a sensitive indicator of $\mathrm{Fe}$ 
Table 8. Daily intakes of essential trace elements and minerals in Germany

Values are medians, with $2 \cdot 5,50$ and 97.5 percentiles

\begin{tabular}{|c|c|c|c|c|c|c|c|}
\hline \multirow[b]{2}{*}{ Element } & \multirow[b]{2}{*}{ Percentiles } & \multicolumn{6}{|c|}{ Age } \\
\hline & & $18-24$ & $25-34$ & $35-44$ & $45-54$ & $55-64$ & $>65$ \\
\hline & & \multicolumn{6}{|c|}{ Females } \\
\hline \multirow{3}{*}{$\mathrm{Ca}(\mathrm{mg})$} & P2.5 & 230 & 238 & 22 & 267 & 324 & 207 \\
\hline & P50 & 667 & 655 & 624 & 639 & 641 & 615 \\
\hline & P97.5 & 1724 & 1400 & 1395 & 1352 & 1388 & 1297 \\
\hline \multirow[t]{3}{*}{$\mathrm{Mg}(\mathrm{mg})$} & P2.5 & 132 & 128 & 134 & 146 & 161 & 154 \\
\hline & P50 & 280 & 280 & 278 & 291 & 299 & 298 \\
\hline & P97.5 & 502 & 509 & 499 & 514 & 476 & 461 \\
\hline \multirow[t]{3}{*}{$\mathrm{Fe}(\mathrm{mg})$} & P2.5 & $4 \cdot 9$ & $5 \cdot 2$ & 5.5 & 6.6 & 5.7 & 6.0 \\
\hline & P50 & 11.6 & 11.7 & 11.8 & $12 \cdot 6$ & $13 \cdot 0$ & 12.5 \\
\hline & P97.5 & $21 \cdot 0$ & 18.9 & 22.0 & $21 \cdot 3$ & 19.9 & $22 \cdot 1$ \\
\hline \multirow[t]{3}{*}{ Zn (mg) } & P2.5 & $4 \cdot 2$ & $4 \cdot 3$ & $4 \cdot 2$ & $4 \cdot 6$ & $4 \cdot 7$ & $4 \cdot 5$ \\
\hline & P50 & 8.6 & 8.9 & $9 \cdot 2$ & $9 \cdot 2$ & $9 \cdot 5$ & $9 \cdot 2$ \\
\hline & P97.5 & $21 \cdot 2$ & 16.6 & $17 \cdot 1$ & $16 \cdot 1$ & 16.6 & $15 \cdot 2$ \\
\hline \multirow[t]{3}{*}{$\mathrm{Cu}(\mathrm{mg})$} & P2.5 & 0.76 & 0.72 & 0.75 & 0.92 & 0.85 & 0.94 \\
\hline & P50 & 1.75 & 1.67 & 1.64 & 1.79 & 1.77 & 1.68 \\
\hline & P97.5 & $3 \cdot 55$ & $3 \cdot 21$ & 2.98 & 2.96 & $3 \cdot 02$ & $3 \cdot 22$ \\
\hline \multirow[t]{4}{*}{ I $(\mu \mathrm{g})$} & P2.5 & 28 & 30 & 29 & 38 & 33 & 40 \\
\hline & P50 & 97 & 124 & 117 & 123 & 121 & 110 \\
\hline & P97.5 & 291 & 373 & 391 & 306 & 325 & 347 \\
\hline & & \multicolumn{6}{|c|}{ Males } \\
\hline \multirow[t]{3}{*}{$\mathrm{Ca}(\mathrm{mg})$} & P2.5 & 289 & 267 & 298 & 270 & 312 & 274 \\
\hline & P50 & 844 & 729 & 733 & 713 & 637 & 650 \\
\hline & P97.5 & 1927 & 1767 & 1616 & 1564 & 1415 & 1269 \\
\hline \multirow[t]{3}{*}{$\mathrm{Mg}$ (mg) } & $P 2 \cdot 5$ & 176 & 181 & 180 & 224 & 211 & 195 \\
\hline & P50 & 386 & 371 & 356 & 346 & 332 & 344 \\
\hline & P97.5 & 640 & 662 & 624 & 566 & 543 & 525 \\
\hline \multirow[t]{3}{*}{$\mathrm{Fe}(\mathrm{mg})$} & P2.5 & 6.5 & $7 \cdot 1$ & 6.6 & 7.3 & 8.0 & 8.6 \\
\hline & P50 & 14.7 & 14.9 & 14.5 & 15.0 & 14.5 & 14.4 \\
\hline & P97.5 & 25.6 & $29 \cdot 4$ & $27 \cdot 3$ & 25.6 & 25.5 & 22.5 \\
\hline \multirow[t]{3}{*}{$\mathrm{Zn}(\mathrm{mg})$} & P2.5 & $5 \cdot 3$ & $5 \cdot 4$ & 5.1 & 6.0 & $6 \cdot 3$ & 5.9 \\
\hline & P50 & 11.7 & 11.8 & $11 \cdot 2$ & 11.6 & 10.6 & $10 \cdot 3$ \\
\hline & P97.5 & $25 \cdot 1$ & $24 \cdot 6$ & $20 \cdot 2$ & $19 \cdot 1$ & 18.8 & 19.0 \\
\hline \multirow{3}{*}{$\mathrm{Cu}(\mathrm{mg})$} & $\mathrm{P} 2 \cdot 5$ & $1 \cdot 12$ & 1.07 & 0.99 & 1.19 & 1.32 & 1.13 \\
\hline & P50 & $2 \cdot 26$ & 2.23 & 2.09 & $2 \cdot 10$ & 1.97 & 1.98 \\
\hline & P97.5 & 3.64 & 4.69 & 3.89 & 3.68 & 3.44 & $2 \cdot 91$ \\
\hline \multirow[t]{3}{*}{ I $(\mu \mathrm{g})$} & P2.5 & 41 & 35 & 36 & 38 & 41 & 48 \\
\hline & P50 & 124 & 130 & 128 & 125 & 117 & 120 \\
\hline & P97.5 & 426 & 368 & 417 & 430 & 372 & 326 \\
\hline
\end{tabular}

status, is also lower than the reference (Table 9). Both of these results taken together are strong evidence of a suboptimal supply of $\mathrm{Fe}$ in young women. The intake of $\mathrm{Ca}$ (Table 8) and the excretion of $\mathrm{Ca}$ in urine indicate that about half of women and about one third of men are not adequately supplied with $\mathrm{Ca}$ (Table 9). This is also true for $\mathrm{I}$, for which the intake as well as the urinary excretion clearly indicate that, in accordance with the WHO criteria, Germany has to be classified as a region of endemic deficiency, grade 1/2 (Table 9). Consequently, a significant increase in the intakes of $\mathrm{I}$ and $\mathrm{Ca}$ is necessary in the German population. 
Table 9. Serum concentrations of selenium, copper, zinc, magnesium, ferritin and urinary excretion of calcium and iodine/24 $h$ in Germany

\begin{tabular}{|c|c|c|c|c|c|}
\hline \multirow[b]{2}{*}{ Serum concentration } & \multicolumn{2}{|c|}{ Median } & \multirow{2}{*}{$\begin{array}{l}\text { Reference } \\
\text { value }\end{array}$} & \multicolumn{2}{|c|}{ Below the reference $(\%)$} \\
\hline & Females & Males & & Females & Males \\
\hline $\mathrm{Se}(\mu \mathrm{mol} / 1$ & $1 \cdot 0$ & 1.0 & $<0.72$ & $2 \cdot 6$ & 3.8 \\
\hline $\mathrm{Cu}(\mu \mathrm{mol} / 1$ & $18 \cdot 2$ & $15 \cdot 2$ & $\begin{array}{r}<11.5 \mathrm{~F} \\
<9.5 \mathrm{M}\end{array}$ & $2 \cdot 4$ & $2 \cdot 7$ \\
\hline $\mathrm{Zn}(\mu \mathrm{mol} / \mathrm{l})$ & $16 \cdot 2$ & $16 \cdot 8$ & $\begin{array}{r}<9.0 \mathrm{~F} \\
<10.6 \mathrm{M}\end{array}$ & $2 \cdot 9$ & $3 \cdot 6$ \\
\hline $\mathrm{Mg}(\mathrm{mmol} / \mathrm{l})$ & 0.77 & 0.77 & $<0.64$ & 3.9 & $1 \cdot 7$ \\
\hline Ferritin $(\mu \mathrm{g} / \mathrm{l})$ & 40 & 108 & $\begin{array}{l}<12 \mathrm{~F} \\
<20 \mathrm{M}\end{array}$ & $11^{*}$ & $4^{*}$ \\
\hline \multicolumn{6}{|l|}{ Urine excretion } \\
\hline $\mathrm{Ca}(\mathrm{mmol} / 24 \mathrm{~h})$ & $2 \cdot 3$ & $3 \cdot 1-4 \cdot 7$ & $<3.3$ & 46 & 37 \\
\hline I $(\mu \mathrm{g} / \mathrm{g}$ creatinine $)$ & $43 \cdot 2$ & $35 \cdot 8$ & $t$ & - & - \\
\hline
\end{tabular}

* Eighteen percent of women (18-24 years) exhibit ferritin levels lower than the reference value.

$\dagger$ Classification of urinary I excretion according to WHO criteria: $100 \mu \mathrm{g} / \mathrm{g}$ creatinine $=$ non-endemic; $51-100 \mu \mathrm{g} / \mathrm{g}$ creatinine $=$ endemic, grade $1 ; 25-50 \mu \mathrm{g} / \mathrm{g}$ creatinine $=$ endemic, grade $2 ;<25 \mu \mathrm{g} / \mathrm{g}$ creatinine $=$ endemic, grade 3.

Table 10. Contribution of various food groups to the daily intake of trace elements and minerals in Germany

\begin{tabular}{|c|c|c|c|}
\hline Element & Food groups & Contribution F (\%) & Contribution $\mathbf{M}(\%)$ \\
\hline \multirow[t]{5}{*}{$\mathrm{Ca}$} & Dairy products & 51 & 52 \\
\hline & Milk & 28 & 27 \\
\hline & Bread & 10 & 11 \\
\hline & Beverages & 15 & 15 \\
\hline & Vegetables & 8 & 7 \\
\hline \multirow[t]{5}{*}{$\mathrm{Mg}$} & Bread & 26 & 28 \\
\hline & Beverages & 18 & 19 \\
\hline & Dairy products & 11 & 9 \\
\hline & Milk & 8 & 7 \\
\hline & Potatoes & 7 & 7 \\
\hline \multirow[t]{5}{*}{$\mathrm{Fe}$} & Bread & 26 & 28 \\
\hline & Meat & 12 & 13 \\
\hline & Potatoes & 5 & 5 \\
\hline & Beverages & 11 & 10 \\
\hline & Sugar/sweets & 3 & 2 \\
\hline \multirow[t]{4}{*}{$\mathrm{Zn}$} & Meat & 18 & 19 \\
\hline & Dairy products & 17 & 15 \\
\hline & Bread & 21 & 22 \\
\hline & Milk & 7 & 6 \\
\hline \multirow[t]{5}{*}{$\mathrm{Cu}$} & Bread & 23 & 24 \\
\hline & Potatoes & 7 & 7 \\
\hline & Meat & 10 & 10 \\
\hline & Beverages & 15 & 18 \\
\hline & Fruits & 7 & 5 \\
\hline \multirow[t]{3}{*}{ I } & Beverages & 57 & 53 \\
\hline & Fish & 13 & 15 \\
\hline & Dairy products & 7 & 6 \\
\hline
\end{tabular}

$\mathrm{F}=$ females; $\mathbf{M}=$ males 
Table 11. Weekly intakes of lead, cadmium and mercury in Germany compared to the Provisional Tolerable Weekly Intake (PTWI)

\begin{tabular}{lcccccc}
\hline \hline & Pb intake & Pb PTWI & Cd intake & Cd PTWI & Hg intake & Hg PTWI \\
\hline Females (58 kg) & 0.745 & 2.9 & 0.148 & 0.435 & 0.094 & 0.29 \\
Males (70 kg) & 0.984 & 3.5 & 0.192 & 0.525 & 0.117 & 0.35 \\
\hline
\end{tabular}

The weekly intakes of toxic trace elements such as $\mathrm{Pb}, \mathrm{Cd}$ and $\mathrm{Hg}$ are lower (Table 11) than the PTWI recommended by the WHO/FAO and cover about one third of the PTWI for these three elements.

Although the VERA Study, in general, documents a reasonably good supply of trace elements and minerals in the German population (with the exception of $\mathrm{Ca}$ and $\mathrm{I}$ ), this does not preclude the possibility that there may be special population groups which are deficient in these elements. More studies are needed to determine the status of various population groups in order to obtain detailed information on those at risk from marginal supplies of essential trace metals and minerals.

In the former GDR, food consumption patterns were different from those in the FRG. This is due to the more limited variety of food available in the GDR; fresh vegetables and tropical fruits were especially scarce. After reunification the exchange of food between the Eastern and Western parts of Germany led to the availability of a similar food range in the whole country. Thus there has been a similar intake of metals in both parts of Germany since 1989 and the supply of these elements as documented in the VERA-Study for the FRG can also be taken as evidence of the present intake of trace elements and minerals in the Eastern part of Germany.

\section{GREAT BRITAIN}

Information on intake of minerals and trace elements is collected in three ways in Great Britain: National Food Survey, Total Diet Study and dietary surveys of individuals. It should be noted that in the UK flour and many breakfast cereals are fortified with certain minerals (e.g. $\mathrm{Fe}, \mathrm{Ca}$ ) and thus can be a significant source.

\section{NATIONAL FOOD SURVEY}

The National Food Survey (NFS) is a continuous survey of British household consumption and expenditure which has been running since 1940. Information on foods purchased by households is collected. 1992 was the first year that confectionery, soft drinks, and alcoholic drinks consumed in the home were included. Intakes for 1993, the latest year for which full results are available (MAFF, 1994a), together with the main food groups that contribute to intake are given in Table 12. Data on minerals other than those listed are not available from the NFS.

\section{TOTAL DIET STUDY}

The UK Total Diet Study, which is carried out continuously, is a model of the national average domestic diet in the UK (Peattie et al. 1983). The quantities of foods that make up the Total Diet are largely based on data from the National Food Survey. Food samples are 
Table 12. National average daily intakes of minerals and trace elements in Great Britain*

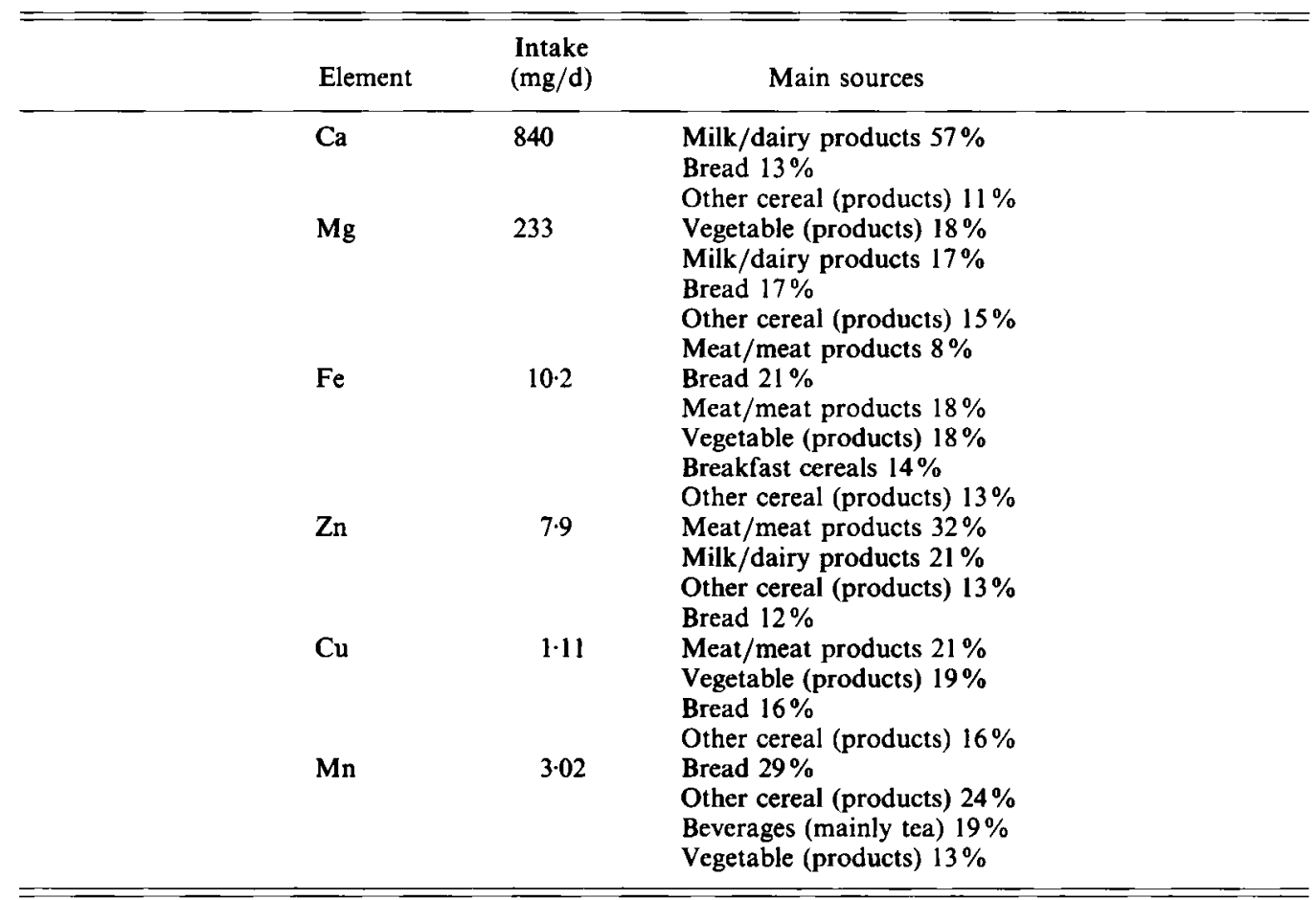

* National Food Survey (MAFF, 1993).

purchased at two-weekly intervals from different locations, selected randomly to be representative of the UK as a whole, and are then transported to one centre where they are prepared and cooked (where necessary) according to normal consumer practice. The prepared samples are stored and analysed for compounds of interest.

Intakes for selected elements are listed in Table 13 together with main sources. In most cases, intakes and sources are very similar to those derived from the NFS.

\section{DIETARY SURVEY OF INDIVIDUALS}

Numerous surveys of individuals have been carried out in Great Britain on a national or regional scale. Data from selected national studies are presented to illustrate variation in mineral intake by age and sex. Variations also occur as a result of other factors, e.g. region and social class or income.

\section{Adults}

The Dietary and Nutritional Survey of British Adults was a detailed survey, undertaken in 1986-7, of nearly 2200 adults, representative of the population aged 16-64 years, but excluding pregnant women (Gregory et al. 1990). Subjects kept a detailed weighed record of all the food and drink that they consumed for seven consecutive days. In addition, information on anthropometric measures, blood pressure, blood and urine constituents and life style and socioeconomic characteristics was collected. 
Table 13. National average daily intakes of minerals and trace elements from the $U K$ Total Diet Study

\begin{tabular}{|c|c|c|c|}
\hline Element & $\begin{array}{c}\text { Year } \\
\text { analysed }\end{array}$ & Intake $(\mathrm{mg} / \mathrm{d})$ & Main sources \\
\hline $\mathrm{Ca}$ & 1991 & $890 \mathrm{mg}$ & $\begin{array}{l}\text { Milk/dairy products } 50 \% \\
\text { Bread } 19 \% \\
\text { Other cereals } 10 \%\end{array}$ \\
\hline $\mathrm{Mg}$ & 1991 & $240 \mathrm{mg}$ & $\begin{array}{l}\text { Vegetables } 23 \% \\
\text { Bread } 17 \% \\
\text { Other cereals } 16 \% \\
\text { Milk/dairy products } 15 \% \\
\text { Meat/meat products } 9 \%\end{array}$ \\
\hline $\mathrm{Fe}$ & 1991 & $10 \cdot 3 \mathrm{mg} *$ & $\begin{array}{l}\text { Vegetables } 27 \% \\
\text { Other cereals } 23 \% \\
\text { Bread } 22 \% \\
\text { Meat } / \text { meat products } 17 \%\end{array}$ \\
\hline $\mathrm{Zn}$ & 1991 & $8.5 \mathrm{mg}^{*}$ & $\begin{array}{l}\text { Meat/meat products } 36 \% \\
\text { Bread } 15 \% \\
\text { Milk/dairy products } 15 \% \\
\text { Other cereals } 13 \%\end{array}$ \\
\hline $\mathrm{Cu}$ & 1991 & $1.22 \mathrm{mg}^{*}$ & $\begin{array}{l}\text { Vegetables } 28 \% \\
\text { Other cereals } 20 \% \\
\text { Bread } 18 \% \\
\text { Meat } / \text { meat products } 17 \%\end{array}$ \\
\hline $\mathbf{M n}$ & 1991 & $5.00 \mathrm{mg}^{*}$ & $\begin{array}{l}\text { Beverages } 45 \% \\
\text { Bread } 20 \% \\
\text { Other cereals } 18 \% \\
\text { Vegetables } 10 \%\end{array}$ \\
\hline I & 1991 & $166 \mu \mathrm{g}^{*}$ & $\begin{array}{l}\text { Milk/dairy products } 37 \% \\
\text { Meat /meat products } 26 \% \\
\text { Fish } 10 \% \\
\text { Eggs } 8 \%\end{array}$ \\
\hline Se & 1985 & $63 \mu \mathrm{g}$ & $\begin{array}{l}\text { Meat /fish and products } 37 \% \\
\text { Bread } 29 \% \\
\text { Milk/dairy products/eggs } 14 \% \\
\text { Other cereals } 8 \%\end{array}$ \\
\hline $\mathrm{Cr}$ & 1985 & $99 \mu \mathrm{g} \dagger$ & $\begin{array}{l}\text { Meat } 22 \% \\
\text { Cereals } 19 \% \\
\text { Vegetables } 19 \% \\
\text { Fruit and sugars } 15 \%\end{array}$ \\
\hline $\mathrm{Pb}$ & 1988 & $60 \mu \mathrm{g}$ & $\begin{array}{l}\text { Bread/other cereals } 19 \% \\
\text { Beverages } 19 \% \\
\text { Vegetables } 18 \% \\
\text { Milk } 10 \% \\
\text { Meat/meat products } 15 \%\end{array}$ \\
\hline $\mathrm{Hg}$ & 1982 & $3 \mu \mathrm{g}$ & $\begin{array}{l}\text { Fish } 38 \% \\
\text { Preserves/fruit/vegetables } 19 \% \\
\text { Meat } 12 \% \\
\text { Beverages } 12 \%\end{array}$ \\
\hline $\mathrm{Cd}$ & 1988 & $19 \mu \mathrm{g}$ & $\begin{array}{l}\text { Bread/cereals } 28 \% \\
\text { Potato } 21 \% \\
\text { Beverages } 12 \%\end{array}$ \\
\hline
\end{tabular}

* Levels less than limit of detection taken as zero.

$\dagger$ Mean concentration used. 
Table 14. Average daily intakes (and Reference Nutrient Intakes*) of minerals and trace elements by British adults, 1986-7

\begin{tabular}{|c|c|c|c|c|c|c|}
\hline Age/sex & $\mathrm{Ca}(\mathrm{mg})$ & $\mathrm{Mg}(\mathrm{mg})$ & $\mathrm{Fe}(\mathrm{mg})$ & $\mathrm{Zn}(\mathrm{mg})$ & $\mathrm{Cu}(\mathrm{mg})$ & $\mathrm{I}(\mu \mathrm{g})$ \\
\hline $16-24 \mathrm{M}$ & $899(700-1000)$ & $304(300)$ & $13.0(11.3-8.7)$ & $10.7(9.5)$ & $1 \cdot 41(1 \cdot 0-1 \cdot 2)$ & $233(140)$ \\
\hline $25-34 \mathrm{M}$ & $933(700)$ & $325(300)$ & $14 \cdot 1(8 \cdot 7)$ & $11 \cdot 3(9.5)$ & $1 \cdot 57(1 \cdot 2)$ & $240(140)$ \\
\hline $35-49 \mathrm{M}$ & $961(700)$ & $336(300)$ & $14 \cdot 5(8 \cdot 7)$ & $11 \cdot 7(9 \cdot 5)$ & $1.82(1.2)$ & $251(140)$ \\
\hline $50-64 \mathrm{M}$ & $952(700)$ & $317(300)$ & $14 \cdot 1(8 \cdot 7)$ & $11.5(9.5)$ & $1.63(1.2)$ & $243(140)$ \\
\hline All men & 940 & 323 & $14 \cdot 0$ & 11.4 & 1.63 & 243 \\
\hline $16-24 \mathrm{~F}$ & $675(700-800)$ & $215(270-300)$ & $11.8(14.8)$ & $7.6(7.0)$ & $1 \cdot 10(1.0-1 \cdot 2)$ & $161(140)$ \\
\hline $25-34 \mathrm{~F}$ & $700(700)$ & $232(270)$ & $11 \cdot 1(14 \cdot 8)$ & $8 \cdot 2(7 \cdot 0)$ & $1 \cdot 16(1 \cdot 2)$ & $168(140)$ \\
\hline $35-49 \mathrm{~F}$ & $764(700)$ & $250(270)$ & $12 \cdot 9(14.8)$ & $8.7(7.0)$ & $1 \cdot 31(1 \cdot 2)$ & $184(140)$ \\
\hline $50-64 \mathrm{~F}$ & $747(700)$ & $238(270)$ & $12 \cdot 9(8 \cdot 7)$ & $8.6(7.0)$ & $1.29(1 \cdot 2)$ & $181(140)$ \\
\hline All women & 730 & 237 & $12 \cdot 3$ & $8 \cdot 4$ & $1 \cdot 23$ & 176 \\
\hline
\end{tabular}

* Department of Health (1991).

Table 15. Average daily intakes (and Reference Nutrient Intakes*) of minerals and trace elements by British infants, 1986

\begin{tabular}{llllllll}
\hline \hline Age group & $\mathrm{Ca}(\mathrm{mg})$ & $\mathrm{Mg}(\mathrm{mg})$ & $\mathrm{Fe}(\mathrm{mg})$ & $\mathrm{Zn}(\mathrm{mg})$ & $\mathrm{Cu}(\mathrm{mg})$ & $\mathrm{Mn}(\mathrm{mg})$ & $\mathrm{I}(\mu \mathrm{g})$ \\
\hline 6-9 months & $744(525)$ & $111(75)$ & $8 \cdot 6(7 \cdot 8)$ & $4 \cdot 3(5 \cdot 0)$ & $0 \cdot 6(0 \cdot 3)$ & $1 \cdot 1$ & $176(60)$ \\
$9-12$ months & $825(525)$ & $140(80)$ & $7 \cdot 7(7 \cdot 8)$ & $4 \cdot 8(5 \cdot 0)$ & $0 \cdot 6(0 \cdot 3)$ & $1 \cdot 2$ & $235(60)$ \\
All infants & 783 & 124 & $8 \cdot 1$ & $4 \cdot 5$ & $0 \cdot 6$ & $1 \cdot 2$ & 204 \\
\hline
\end{tabular}

* Department of Health (1991).

Mean intakes of minerals and trace elements from all sources by men and women in four age groups and the recommendations are presented in Table 14. Further information on distribution of intakes is available (Gregory et al. 1990; MAFF, 1994b).

\section{Infants, age 6-12 months}

This survey was carried out in 1986 on a nationally representative sample of 488 infants age between 6 and 12 months (Mills \& Tyler, 1992). Each mother completed a seven-day quantitative record of all the food and drink consumed by her infant.

Average (mean) daily intakes and the recommendations of minerals and trace elements are given in Table 15.

The main sources of minerals were generally cows' milk and commercial infant foods (including infant formulae) although 'family foods' became more important in the older age group.

\section{Children, age $1.5-4.5$ years}

The National Diet and Nutrition Survey (Gregory et al. 1995) was carried out in 1992-3 on a nationally representative sample of nearly 1700 children, age $1.5-4.5$ years (Table 16). The parent or carer of each child kept a detailed weighed record of all the food and drink consumed over four consecutive days (including Saturday and Sunday). The survey also included an interview to provide information on socio-demographic circumstances of the child's household, medication and eating and drinking habits, a record of bowel movement 
Table 16. Average daily intakes (and Reference Nutrient Intakes*) of minerals and trace elements by British children age 1.5-4.5 years, 1992-3

\begin{tabular}{|c|c|c|c|c|c|c|c|}
\hline $\begin{array}{l}\text { Age (years) } \\
\text { and sex }\end{array}$ & $\mathrm{Ca}(\mathrm{mg})$ & $\mathrm{Mg}(\mathrm{mg})$ & $\mathrm{Fe}(\mathrm{mg})$ & $\mathrm{Zn}(\mathrm{mg})$ & $\mathrm{Cu}(\mathrm{mg})$ & $\mathrm{Mn}(\mathrm{mg})$ & $I(\mu \mathrm{g})$ \\
\hline $1 \cdot 5-2 \cdot 5$ & $663(350)$ & $132(85)$ & $5 \cdot 0(6.9)$ & $4 \cdot 3(5)$ & $0.4(0.4)$ & $1 \cdot 1$ & $123(70)$ \\
\hline $2 \cdot 5-3 \cdot 5$ & $635(350)$ & $137(85)$ & $5.6(6.9)$ & $4 \cdot 4(5)$ & $0.5(0.4)$ & $1 \cdot 2$ & $117(70)$ \\
\hline $\begin{array}{r}3 \cdot 5-4 \cdot 5 \\
\text { (boys) }\end{array}$ & $625(350-450)$ & $146(85-120)$ & $6 \cdot 2(6 \cdot 1-6 \cdot 9)$ & $4 \cdot 7(5-6 \cdot 5)$ & $0.5(0.4-0.6)$ & 1.4 & $121(70-100)$ \\
\hline $\begin{array}{r}3 \cdot 5-4 \cdot 5 \\
\text { (girls) }\end{array}$ & $595(350-450)$ & $137(85-120)$ & $5.9(6 \cdot 1-6.9)$ & $4 \cdot 4(5-6 \cdot 5)$ & $0.5(0.4-0.6)$ & $1 \cdot 3$ & $113(70-100)$ \\
\hline
\end{tabular}

* Department of Health, 1991.

Table 17. Average daily intake (and Reference Nutrient Intake*) of calcium and iron by British school children, 1983

\begin{tabular}{lll}
\hline Age/sex & Ca (mg) & Fe (mg) \\
Boys, 10-11 years & $833(550-1000)$ & $10 \cdot 0(8 \cdot 7-11 \cdot 3)$ \\
Girls, 10-11 years & $702(550-800)$ & $8 \cdot 6(8 \cdot 7-14 \cdot 8)$ \\
Boys, 14-15 years & $925(1000)$ & $12 \cdot 2(11 \cdot 3)$ \\
Girls, 14-15 years & $692(800)$ & $9 \cdot 3(14 \cdot 8)$ \\
\hline
\end{tabular}

* Department of Health, 1991.

Table 18. Average calcium and iron intakes (and Reference Nutrient Intakes*) of 15-25-year-olds, 1982, in the UK

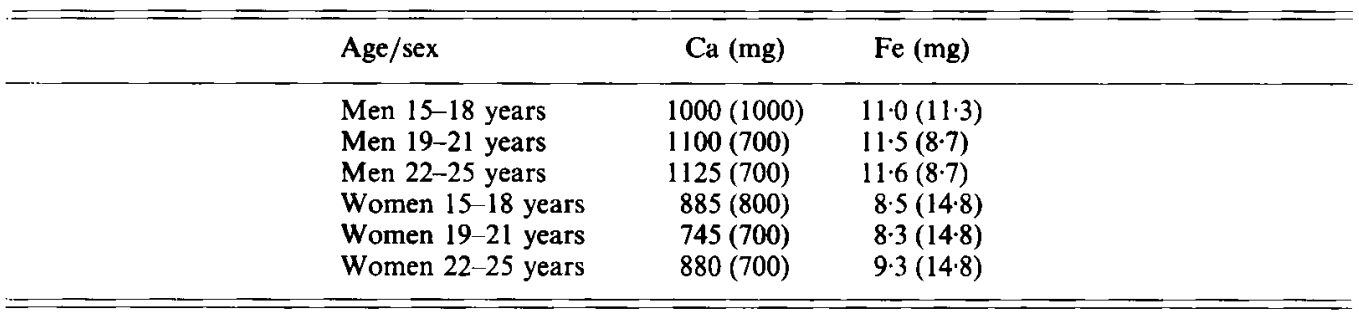

* Department of Health, 1991.

during the food recording period, physical measurements of the child (including height and weight) and dental examination. Where consent was given, a sample of blood was collected to provide information on nutritional status.

Dietary supplements provided negligible $\mathrm{Ca}, \mathrm{Mg}, \mathrm{Zn}, \mathrm{Cu}, \mathrm{Mn}$ and $\mathrm{I}$ for the children in this survey.

\section{School children}

A survey of about 2700 school children age 10-11 and 14-15 years was undertaken in 1983 (Department of Health, 1989). Food and nutrient intakes were measured by a 7-day weighed record. Of the minerals, only $\mathrm{Ca}$ and $\mathrm{Fe}$ were surveyed and are presented in Table 17. 
The main source of $\mathrm{Ca}$ was liquid milk; other major sources were bread, cheese and puddings. The main sources of Fe were bread and breakfast cereals and, to a lesser extent, chips, meat and meat products.

\section{5-25-year-olds}

In this survey, undertaken in 1982, about 1000 individuals kept a two-week semiquantitative dietary record (Bull, 1985). Fe and $\mathrm{Ca}$ were measured in three age groups (15-18, 19-21 and 22-25 years; Table 18).

\section{IRELAND (REPUBLIC AND NORTHERN IRELAND)}

\section{MINERAL INTAKE DATA FOR THE REPUBLIC OF IRELAND}

The data are taken from the National Nutrition Survey, 1990 (INDI, 1990). The dietary intake of a representative sample of the Irish population over 18 years of age $(n=676)$ and of Irish school-going children from 8 to 18 years $(n=538)$ was assessed. The school children sampled were from primary and secondary schools.

The intake of the selected elements $(\mathrm{Fe}, \mathrm{Ca}$ and $\mathrm{Zn}$ ) was assessed by the (7-day) dietary history method in conjunction with a food atlas to estimate portion sizes. The nutrient content of the food intake was determined using a computerized version of food tables (McCance \& Widdowson, 1991), modified to take account of Irish bread composition. Table 19 summarizes the intake of $\mathrm{Fe}, \mathrm{Ca}$ and $\mathrm{Zn}$ in males and Table 20 the intake in females. Mean intake values are presented as well as the intake as a percentage of the RDA for the age groups indicated.

The food groups contributing most to the daily $\mathrm{Fe}$ intake are: meat and meat products, $20-30 \%$; bread, $18-30 \%$; breakfast cereals, $7-24 \%$; potatoes, $7-12 \%$; biscuits/cakes/ desserts, $6-11 \%$.

For Ca these groups are: milk, 35-55\% ; bread, $12-22 \%$; other dairy products, $5-13 \%$; biscuits/cakes/desserts, 7-10\%.

For $\mathrm{Zn}$ the more important groups are: meat and meat products, $35-49 \%$; bread, 12-24\%; milk, 9-20\%; potatoes, 5-9\%.

\section{MINERAL INTAKE DATA FOR NORTHERN IRELAND}

The data are taken from the Northern Ireland Diet and Health Study (Strain et al., 1990a). The dietary intake of nutrients among a representative sample of the Northern Irish population was assessed. The population comprised adults age 16-64 years, excluding pregnant women and physically and mentally handicapped individuals. The method used to assess the intake of the selected elements was the Weighed Inventory Technique which involved the participants weighing all food and drink consumed for a 7-day period and entering the recorded weights and descriptions in a food diary. Nutrient intakes were calculated from a standard computerized version of McCance \& Widdowson's (1991) food tables.

In Table 21 the $\mathrm{Fe}$ intakes by various age/sex groups are shown and compared with the 'Dietary Reference Values (DRV) for Food Energy and Nutrients for the United Kingdom' (Department of Health, 1991). Iron status from blood measurements has been evaluated in this population (Strain et al. 1990b) and compared with dietary data (Strain \& Thompson, 1991). 
Table 19. Daily intakes of iron, calcium and zinc in males in the Republic of Ireland Values are means \pm SD (mg), and \% of Recommended Daily Allowances (RDA)

\begin{tabular}{|c|c|c|c|c|c|c|c|c|c|}
\hline \multirow{2}{*}{$\begin{array}{l}\text { Age group (years) } \\
\text { and sample size }\end{array}$} & \multicolumn{3}{|c|}{$\mathrm{Fe}$} & \multicolumn{3}{|c|}{$\mathrm{Ca}$} & \multicolumn{3}{|c|}{$\mathrm{Zn}$} \\
\hline & Mean & SD & RDA $\%$ & Mean & SD & RDA \% & Mean & SD & RDA $\%$ \\
\hline $8-12(n=85)$ & $12 \cdot 9$ & $4 \cdot 6$ & 129 & 1227 & 542 & 154 & $10 \cdot 1$ & 3.6 & 101 \\
\hline $12-15(n=93)$ & $14 \cdot 7$ & $4 \cdot 7$ & 113 & 1208 & 507 & 101 & $11 \cdot 7$ & 3.9 & 78 \\
\hline $15-18(n=73)$ & $19 \cdot 3$ & $7 \cdot 9$ & 138 & 1549 & 629 & 129 & $15 \cdot 1$ & 4.9 & 101 \\
\hline $18-25(n=51)$ & $15 \cdot 4$ & $4 \cdot 9$ & 154 & 1391 & 710 & 174 & $14 \cdot 5$ & $5 \cdot 3$ & 97 \\
\hline $25-40(n=85)$ & $15 \cdot 0$ & $4 \cdot 0$ & 150 & 1361 & 588 & 170 & $14 \cdot 4$ & $4 \cdot 2$ & 96 \\
\hline $40-60(n=87)$ & $13 \cdot 1$ & $4 \cdot 8$ & 131 & 968 & 527 & 121 & $12 \cdot 5$ & $3 \cdot 6$ & 83 \\
\hline$>60(n=82)$ & $11 \cdot 2$ & $4 \cdot 1$ & 112 & 958 & 441 & 120 & $11 \cdot 2$ & $4 \cdot 2$ & 75 \\
\hline
\end{tabular}

Table 20. Daily intakes of iron, calcium and zinc in females in the Republic of Ireland Values are means \pm SD (mg), and \% of Recommended Daily Allowances (RDA)

\begin{tabular}{|c|c|c|c|c|c|c|c|c|c|}
\hline \multirow{2}{*}{$\begin{array}{l}\text { Age group (years) } \\
\text { and sample size }\end{array}$} & \multicolumn{3}{|c|}{$\mathrm{Fe}$} & \multicolumn{3}{|c|}{$\mathrm{Ca}$} & \multicolumn{3}{|c|}{$\mathrm{Zn}$} \\
\hline & Mean & SD & RDA \% & Mean & SD & RDA \% & Mean & SD & RDA \% \\
\hline $8-12(n=63)$ & $11 \cdot 0$ & $4 \cdot 3$ & 110 & 1039 & 489 & 130 & 8.9 & 3.5 & 89 \\
\hline $12-15(n=114)$ & $12 \cdot 4$ & $4 \cdot 6$ & 89 & 962 & 363 & 80 & $9 \cdot 7$ & 3.0 & 65 \\
\hline $15-18(n=110)$ & $11 \cdot 6$ & $3 \cdot 8$ & 83 & 950 & 432 & 79 & $9 \cdot 7$ & $2 \cdot 9$ & 65 \\
\hline $18-25(n=54)$ & 10.8 & 4.9 & 77 & 927 & 432 & 116 & $9 \cdot 1$ & 3.9 & 61 \\
\hline $25-40(n=122)$ & 10.8 & $4 \cdot 4$ & 77 & 891 & 472 & 111 & $9 \cdot 4$ & $3 \cdot 3$ & 63 \\
\hline $40-60(n=111)$ & $10 \cdot 0$ & $3 \cdot 7$ & 71 & 793 & 342 & 99 & 8.9 & $3 \cdot 4$ & 59 \\
\hline$>60(n=84)$ & 9.8 & $3 \cdot 4$ & 109 & 831 & 365 & 104 & $9 \cdot 1$ & $2 \cdot 9$ & 61 \\
\hline
\end{tabular}

Table 21. Dietary intakes of iron among various age/sex groups in Northern Ireland Values are means \pm SD $(\mathrm{mg})$, and \% of Dietary Reference Value (DRV)*

\begin{tabular}{|c|c|c|c|c|c|c|}
\hline \multirow[b]{2}{*}{ Age group (years) } & \multicolumn{3}{|c|}{ Fe intake of males } & \multicolumn{3}{|c|}{ Fe intake of females } \\
\hline & Mean & SD & DRV \% & Mean & SD & DRV \% \\
\hline $\begin{array}{l}16-29(n=105 \mathrm{M}, n=110 \mathrm{~F}) \\
30-39(n=64 \mathrm{M}, n=90 \mathrm{~F}) \\
40-49(n=51 \mathrm{M}, n=70 \mathrm{~F}) \\
50-64(n=38 \mathrm{M}, n=64 \mathrm{~F}) \\
\text { Total }(16-64)\end{array}$ & $\begin{array}{l}13 \cdot 3 \\
14 \cdot 2 \\
12 \cdot 8 \\
14 \cdot 9 \\
13 \cdot 6\end{array}$ & $\begin{array}{l}6 \cdot 4 \\
4 \cdot 4 \\
4 \cdot 9 \\
6 \cdot 1 \\
5 \cdot 6\end{array}$ & $\begin{array}{l}198 \\
212 \\
191 \\
222 \\
-\end{array}$ & $\begin{array}{r}10 \cdot 6 \\
10 \cdot 5 \\
10 \cdot 8 \\
9 \cdot 1 \\
10 \cdot 3\end{array}$ & $\begin{array}{l}5 \cdot 6 \\
4 \cdot 8 \\
4 \cdot 4 \\
2 \cdot 7 \\
4 \cdot 7\end{array}$ & $\begin{array}{r}93 \\
92 \\
95 \\
136 \\
-\end{array}$ \\
\hline
\end{tabular}

* Department of Health (1991).

\section{IT ALY}

The data received from Italy are based on the dietary intakes of elderly people (Scaccini $e t$ al. 1992; Freudenheim et al. 1993). The nutrient intake data, including $\mathrm{Fe}$ and $\mathrm{Ca}$, were based on a study of the nutritional status of Italian elderly conducted in 1983-7. Italians age 60 or over living in 14 centres throughout Italy were sampled. The final sample 
Table 22. Daily intakes of iron and calcium by Italian elderly men and women, age 60 years and older, based on a food consumption survey

Values are means $\pm S E M$

\begin{tabular}{|c|c|c|}
\hline Element & Females $(\mathrm{mg} / \mathrm{d})$ & Males $(\mathrm{mg} / \mathrm{d})$ \\
\hline $\begin{array}{l}\mathrm{Fe} \\
\mathrm{Ca}\end{array}$ & $\begin{array}{c}9 \pm 0.13 \\
615 \pm 12\end{array}$ & $\begin{array}{l}11 \pm 0 \cdot 19 \\
718 \pm 15\end{array}$ \\
\hline
\end{tabular}

included 449 males and 496 females (42\% from retirement homes, the others free-living from urban and rural areas). For seven consecutive days, all foods and beverages consumed were weighed and recorded. All foods recorded were aggregated into main food groups. A final list of foods contributed up to $90 \%$ of the intake of various micronutrients. The calculated mean intakes of $\mathrm{Fe}$ and $\mathrm{Ca}$ by elderly men and women are presented in Table 22.

The proportion of subjects whose nutrient requirements were not met by diet $(67 \%$ of the RDA is used as cutoff point) was estimated as $50 \%$ for $\mathrm{Ca}$. For $\mathrm{Fe}, 25 \%$ of the women were evaluated as having inadequate diets. The food groups contributing most to the daily $\mathrm{Ca}$ intake are whole milk (17\% contribution), medium fat cheese $(13 \%)$, other cheeses $(21 \%)$, skimmed milk $(10 \%)$. For Fe the most important sources are wine $(19 \%$ contribution), pasta $(8 \%)$, white bread $(8 \%)$, beef $(7 \%)$ and legumes $(5 \%)$.

\section{THE NETHERLANDS}

The dietary intakes of various toxic and essential minerals and trace elements among 20 age/gender groups in the Netherlands were assessed. Two hundred and twenty six food items, representing approximately $95 \%$ of the weight content of the average Dutch diet, according to the first Dutch national food consumption survey $(1987-8, n=5898$, two-day record), were purchased, prepared and analysed. In the 'remaining' (not analysed) c. 600 food items of the survey, concentrations of elements were estimated using the Netherlands Nutrient Database (Anon. 1994) and international food tables (McCance \& Widdowson, 1991). Daily intake figures were calculated and compared with the Dutch RDA for each essential element and the ADI, as established by the WHO, for toxic elements. The food groups with the highest contribution to the daily intake were also calculated.

Table 23 gives the mean daily intake of $\mathrm{Cd}$ and $\mathrm{Pb}$ for various age/gender categories (Brussaard et al. 1994) and is compared with the ADI derived from the PTWI levels established by the WHO.

Table 24 presents the mean daily intake of a number of essential elements and the percentage of the age/gender group with an intake lower than $80 \%$ of the RDA or lower level of the safe and adequate intake (Van Dokkum et al. 1994). The estimated values of the unanalysed foods are included.

In Table 25 the food groups contributing most to the daily intake of the various elements are listed.

Our results indicate that the mean intakes of $\mathrm{Pb}$ and $\mathrm{Cd}$ are well below the age-specific PTDI. For the younger age groups maximum intakes of $\mathrm{Pb}$ and $\mathrm{Cd}$ exceeding the PTDI were found occasionally (not more than $1.5 \%$ ). As it concerns vulnerable age groups, this result should be evaluated critically. However, it should be noted that FAO/WHO assessed a PTWI, indicating that risk assessment should be based on habitual intake rather than on 
Table 23. Dietary intakes of cadmium and lead in various population groups in the Netherlands

Values are means $\pm s D$, and Acceptable Daily Intakes

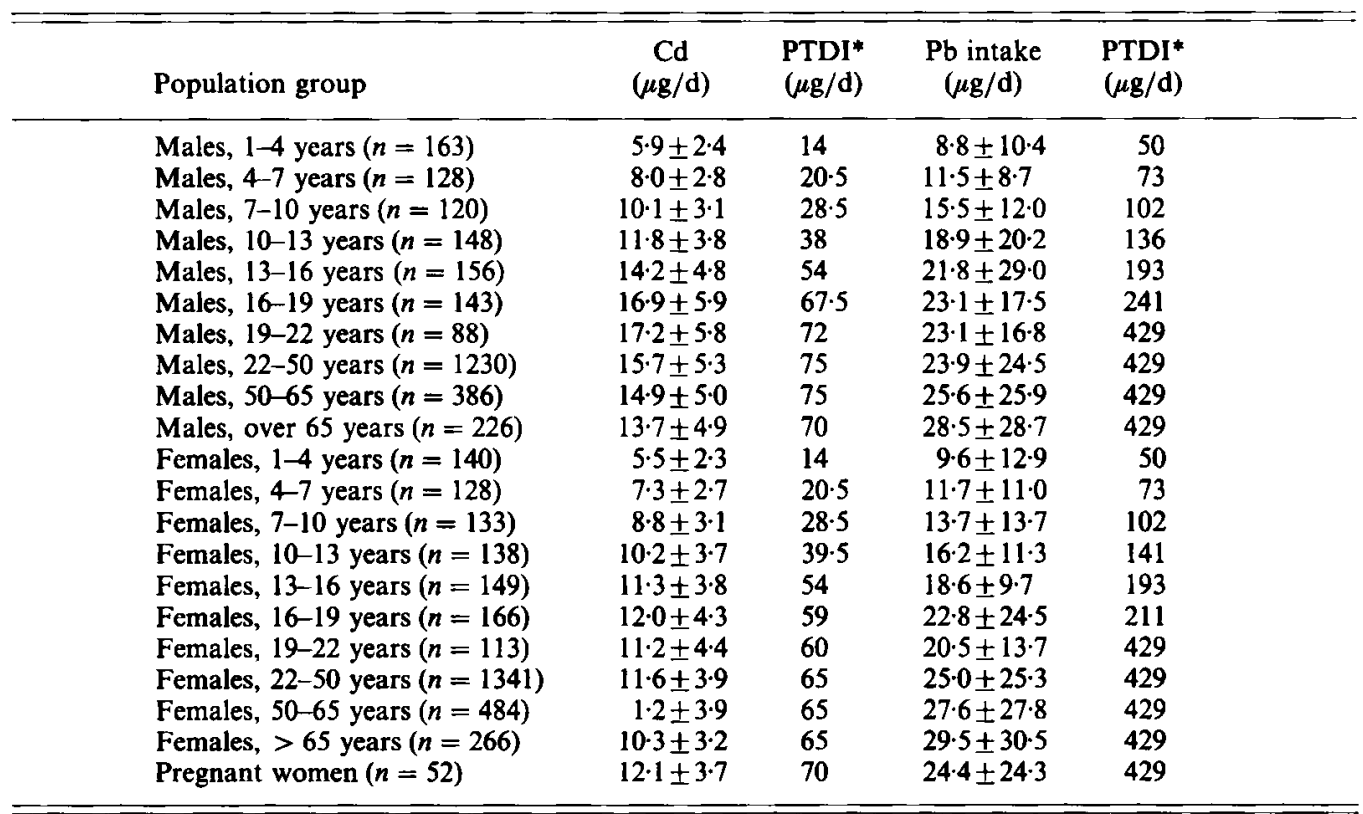

- PTDI (provisional tolerable daily intake), calculated from the official Provisional Tolerable Weekly Intake (WHO/FAO).

Table 24. Mean dietary intakes of essential minerals and trace elements in various population groups in the Netherlands and the percentage of each group with an intake lower than $80 \%$ of the RDA (only group $\% \geqslant 5 \%$ are listed)

\begin{tabular}{|c|c|c|c|c|c|c|}
\hline Age/sex & $\mathrm{Ca}(\mathrm{mg})$ & $\mathrm{Mg}$ (mg) & $\mathrm{Fe}(\mathrm{mg})$ & $\mathrm{Zn}$ (mg) & $\mathrm{Cu}(\mathrm{mg})$ & Se $(\mu \mathrm{g})$ \\
\hline $1-4 M$ & 819 & 186 & $6 \cdot 2(40 \%)$ & 6.0 & 0.6 & 24 \\
\hline $4-7 \mathrm{M}$ & 858 & 218 & $8.1(10 \%)$ & $7 \cdot 1$ & 0.7 & 30 \\
\hline $7-10 \mathrm{M}$ & 884 & 244 & $9 \cdot 5$ & $8 \cdot 3$ & 0.9 & 33 \\
\hline $10-13 \mathrm{M}$ & $960(22 \%)$ & 278 & $10.9(18 \%)$ & $9 \cdot 6$ & $1.0(18 \%)$ & $38(10 \%)$ \\
\hline $13-16 \mathrm{M}$ & $1016(25 \%)$ & $312(5 \%)$ & $12.5(45 \%)$ & $11.0(18 \%)$ & $1.2(55 \%)$ & $44(20 \%)$ \\
\hline $16-19 \mathrm{M}$ & $1194(15 \%)$ & $362(10 \%)$ & $13.7(35 \%)$ & $12 \cdot 2(22 \%)$ & $1.3(42 \%)$ & $49(20 \%)$ \\
\hline $19-22 \mathrm{M}$ & $1042(15 \%)$ & $371(8 \%)$ & $14.5(8 \%)$ & $12 \cdot 3(8 \%)$ & $1.3(42 \%)$ & $48(30 \%)$ \\
\hline $22-50 \mathrm{M}$ & $1099(10 \%)$ & $383(5 \%)$ & 13.7 & $12 \cdot 1(10 \%)$ & $1.2(58 \%)$ & $54(20 \%)$ \\
\hline $50-65 \mathrm{M}$ & $1021(15 \%)$ & $342(10 \%)$ & $13.0(5 \%)$ & $11 \cdot 7(12 \%)$ & $1 \cdot 1(68 \%)$ & $52(28 \%)$ \\
\hline$>65 \mathrm{M}$ & $992(10 \%)$ & $317(18 \%)$ & $12 \cdot 3$ & $11 \cdot 2(15 \%)$ & $1.0(70 \%)$ & $51(35 \%)$ \\
\hline $1-4 F$ & 751 & 172 & $5.8(50 \%)$ & $5.7(8 \%)$ & 0.5 & 22 \\
\hline $4-7 \mathrm{~F}$ & 801 & 200 & $7 \cdot 2(20 \%)$ & $6.7(5 \%)$ & 0.7 & 27 \\
\hline $7-10 \mathrm{~F}$ & $854(8 \%)$ & 230 & $8.4(12 \%)$ & $7.5(5 \%)$ & 0.8 & 30 \\
\hline $10-13 \mathrm{~F}$ & $927(12 \%)$ & 258 & $10 \cdot 0(35 \%)$ & $8.8(5 \%)$ & $0.9(48 \%)$ & $36(12 \%)$ \\
\hline $13-16 \mathrm{~F}$ & $908(18 \%)$ & 271 & $11 \cdot 1(38 \%)$ & $9.6(45 \%)$ & $1.0(78 \%)$ & $38(35 \%)$ \\
\hline $16-19 \mathrm{~F}$ & $878(18 \%)$ & $266(8 \%)$ & $10.6(62 \%)$ & $9.5(20 \%)$ & $1.0(80 \%)$ & $39(45 \%)$ \\
\hline $19-22 \mathrm{~F}$ & $858(22 \%)$ & $269(18 \%)$ & $10.6(78 \%)$ & $9.5(18 \%)$ & $1.0(82 \%)$ & $40(60 \%)$ \\
\hline $22-50 \mathrm{~F}$ & $943(15 \%)$ & $290(10 \%)$ & $10.9(68 \%)$ & $9.7(15 \%)$ & $1.0(80 \%)$ & $42(50 \%)$ \\
\hline $50-65 \mathrm{~F}$ & $902(20 \%)$ & $275(12 \%)$ & $10.6(5 \%)$ & $9.5(20 \%)$ & $0.9(85 \%)$ & $42(50 \%)$ \\
\hline$>65 \mathrm{~F}$ & $895(20 \%)$ & $263(15 \%)$ & $10 \cdot 1(5 \%)$ & $9 \cdot 3(18 \%)$ & $0.9(88 \%)$ & $40(58 \%)$ \\
\hline Pregnancy & $1146(10 \%)$ & $309(18 \%)$ & $10.9(67 \%)$ & $10-0(70 \%)$ & $1.0(92 \%)$ & $43(92 \%)$ \\
\hline
\end{tabular}


Table 25. Contribution (\%) of various food groups to the intake of essential elements in The Netherlands

\begin{tabular}{|c|c|c|c|c|c|}
\hline Element & Food groups & Contribution (\%) & Element & Food groups & Contribution (\%) \\
\hline \multirow[t]{5}{*}{$\mathrm{Ca}$} & Dairy Products & 46 & \multirow[t]{5}{*}{$\mathrm{Zn}$} & Meat/meat products & 28 \\
\hline & Milk & 27 & & Dairy products & 19 \\
\hline & Bread & 6 & & Bread & 16 \\
\hline & Beverages & 5 & & Milk & 9 \\
\hline & Leafy vegetables & 2 & & Soups & 5 \\
\hline \multirow[t]{5}{*}{$\mathrm{Mg}$} & Bread & 22 & \multirow[t]{5}{*}{$\mathrm{Cu}$} & Bread & 23 \\
\hline & Beverages & 17 & & Potatoes & 15 \\
\hline & Dairy products & 12 & & Meat/meat products & 8 \\
\hline & Milk & 9 & & Beverages & 5 \\
\hline & Potatoes & 7 & & Fresh fruits & 5 \\
\hline \multirow[t]{5}{*}{$\mathrm{Fe}$} & Bread & 26 & \multirow[t]{5}{*}{$\mathrm{Se}$} & Meat/meat products & 24 \\
\hline & Meat/meat products & 14 & & Poultry/eggs & 15 \\
\hline & Potatoes & 12 & & Dairy products & 14 \\
\hline & Beverages & 11 & & Bread & 13 \\
\hline & Sugar/sweets & 5 & & Milk & 6 \\
\hline
\end{tabular}

Calculations are based on the total sample of the National Food Consumption Survey 1987-8

incidental intake. The data presented are based on 2-day dietary records, which is more representative of actual than of chronic intake.

The average intake of $\mathrm{Cu}$ was substantially below the RDA for most population groups of 10 years and older. These results suggest that the intake of $\mathrm{Cu}$ may be inadequate for part of the Dutch population. However, the scientific basis for the RDA for Cu is not as firm as for other nutrients, reflecting the uncertainty about the quantitative human requirements for $\mathrm{Cu}$.

The mean intake of Fe was found to be below the RDA for males age 1-4 and 13-19 and for females age $1-4$ and $10-49$. For $\mathrm{Fe}$, the average minimum requirement as a percentage of the Dutch RDA is $80-100 \%$, which means a small margin of safety. The significance of the cutoff point of $80 \%$ as applied in Table 24 is, therefore, higher than for e.g. Ca, for which the average minimum requirement is 50-67\% of the RDA. The Dutch RDA is based on a haem/non-haem Fe ratio of $1: 3$. We did not analyse these two forms of Fe separately, but the calculated values for the first Dutch national food consumption survey indicate that for most population groups less than $20 \%$ of the Fe intake is from haem Fe. As haem Fe is more available for absorption than non-haem $\mathrm{Fe}$, the significance of the observed low Fe intakes is substantial.

The adequate range of Se intake for adults has been set, on the basis of present knowledge of Se nutrition, at 50-159 $\mu \mathrm{g}$ /day (Netherlands Food and Nutrition Council, 1992). The adequate range of intake for other age groups was deduced from the mentioned range for adults in conjunction with reference body weight. As the lower level of the adequate range suggests the requirements for $\mathrm{Se}$, the Se intake data are evaluated taking this lower level into account. From the results of Table 24 some concern can be expressed regarding the Se intake of particularly males age 19-22, females from the age of 13 years, and pregnant women, all having mean Se intakes below the lower level of the adequate range.

Although for $\mathrm{Zn}$ and $\mathrm{Mg}$ the percentage of some population groups with intakes lower than the RDA is not to be neglected, when the average minimum requirements and/or the adequate levels of intake are applied (Netherlands Food and Nutrition Council, 1992), it 
can be concluded that on average no concern can be expressed regarding the intakes of both minerals in the Netherlands.

The Netherlands Food and Nutrition Council (1992) has set the range for the minimum Ca requirement for adults at $400-600 \mathrm{mg} / \mathrm{day}$. This range is higher for elderly persons and, in particular, for post-menopausal women than for younger adults. The $\mathrm{Ca}$ requirement for the elderly may be more close to the upper limit of the mentioned range than for young adults (Netherlands Food and Nutrition Council, 1992). For other age/gender groups no minimum requirements can be set. Less than $10 \%$ of the adult population groups had intakes lower than the lower level of the requirements. The mean $\mathrm{Ca}$ intakes by adults are, however, well above the minimum requirement levels.

The overall results of the study indicate that a substantial proportion of the population has intakes much lower than those recommended, particularly of $\mathrm{Fe}, \mathrm{Se}$ and $\mathrm{Cu}$. This was more apparent for women than for men. It is recommended that the status of these elements should be assessed in defined population groups in order to evaluate the intake findings.

\section{NORWAY}

Two recent studies are reported. One covers the dietary intake among 13- and 18-year-old males and females, a second study group consisted of elderly subjects.

\section{CALCIUM, IRON AND MAGNESIUM INTAKES AMONG 13- AND 18-YEAR-OLD MALES AND FEMALES}

The dietary intake was measured with a validated quantitative food frequency questionnaire, aiming to cover the whole diet. The 12-page questionnaire has questions about 180 food items grouped together according to typical Norwegian meal patterns and covers the 'usual' intake over the past year. The questionnaire was developed from one used for adults, but validated in a group of adolescents (Frost Anderson et al. 1995a, b).

Daily intakes of foods and nutrients were computed using a food data base and software systems developed at the Section for Dietary Research, University of Oslo. Cod liver oil, vitamin and mineral preparations were not included in the calculations. The subjects included 832 13-year-old males, 873 13-year-old females, 710 18-year-old males and 854 18year-old females. Table 26 presents the daily $\mathrm{Ca}, \mathrm{Fe}$ and $\mathrm{Mg}$ intakes as means and some percentile values, compared with the Nordic recommendations (Nes et al. 1993).

\section{CALCIUM, IRON AND MAGNESIUM INTAKES AMONG 75-76-YEAR-OLD MALES AND FEMALES}

The dietary intake was assessed by a modified dietary history method (Nes et al. 1993). During the 1-2 $\mathrm{h}$ interviews the subjects were asked to quantify their daily, weekly and/or monthly meals and snacks. Some food items were weighed in commonly used utensils, other amounts were recorded in household measures. Data processing was similar to that reported for 13- and 18-year-old males/females. The study group consisted of a random sample of 60 subjects, age 75-76 years, living in a rural municipality; it was part of the Euronut investigation into Nutrition and the Elderly in Europe (SENECA). Table 27 presents the intake data of the three elements among the 4 age/gender groups. 
Table 26. Intakes of calcium, iron and magnesium among 13-and 18-year-old males and females in Norway, with percentiles

\begin{tabular}{|c|c|c|c|c|}
\hline & $\begin{array}{c}13 \text { year females } \\
(n=873)\end{array}$ & $\begin{array}{c}13 \text { year males } \\
(n=832)\end{array}$ & $\begin{array}{c}18 \text { year females } \\
(n=854)\end{array}$ & $\begin{array}{l}18 \text { year males } \\
(n=710)\end{array}$ \\
\hline \multicolumn{5}{|l|}{$\mathrm{Ca}(\mathrm{mg} / \mathrm{d})$} \\
\hline Mean (SD) & $1279(539)$ & $1716(767)$ & $1136(453)$ & $1692(681)$ \\
\hline P10 & 695 & 883 & 602 & 908 \\
\hline P25 & 910 & 1203 & 792 & 1236 \\
\hline P50 & 1207 & 1624 & 1078 & 1626 \\
\hline Recommendation & 800 & 800 & 800 & 800 \\
\hline \multicolumn{5}{|l|}{$\mathrm{Fe}(\mathrm{mg} / \mathrm{d})$} \\
\hline Mean (SD) & $12 \cdot 3(4 \cdot 6)$ & $16.8(7 \cdot 2)$ & $11 \cdot 4(3 \cdot 7)$ & $17.0(6 \cdot 7)$ \\
\hline P10 & 7.4 & $9 \cdot 6$ & $7 \cdot 4$ & $10 \cdot 1$ \\
\hline P25 & $9 \cdot 5$ & $12 \cdot 0$ & $9 \cdot 0$ & $12 \cdot 3$ \\
\hline P50 & 11.6 & 15.6 & $10 \cdot 9$ & $15 \cdot 7$ \\
\hline Recommendation & $12-18$ & 12 & $12-18$ & 12 \\
\hline \multicolumn{5}{|l|}{$\mathrm{Mg}(\mathrm{mg} / \mathrm{d})$} \\
\hline Mean (SD) & $418(158)$ & $572(239)$ & $383(126)$ & $597(247)$ \\
\hline P10 & 256 & 326 & 246 & 360 \\
\hline P25 & 320 & 409 & 293 & 443 \\
\hline P50 & 393 & 525 & 363 & 546 \\
\hline Recommendation & 300 & 350 & 300 & 400 \\
\hline
\end{tabular}

Table 27. Calcium, iron and magnesium intakes among 75-76-year-old males and females in Norway

\begin{tabular}{lccccccc}
\hline & \multicolumn{2}{c}{$\mathrm{Ca}(\mathrm{mg} / \mathrm{d})$} & & \multicolumn{2}{c}{$\mathrm{Fe}(\mathrm{mg} / \mathrm{d})$} & & \multicolumn{2}{c}{$\mathrm{Mg}(\mathrm{mg} / \mathrm{d})$} \\
\cline { 2 - 5 } & $\begin{array}{c}\text { Males } \\
(n=32)\end{array}$ & $\begin{array}{c}\text { Females } \\
(n=28)\end{array}$ & $\begin{array}{c}\text { Males } \\
(n=32)\end{array}$ & $\begin{array}{c}\text { Females } \\
(n=28)\end{array}$ & $\begin{array}{c}\text { Males } \\
(n=32)\end{array}$ & $\begin{array}{c}\text { Females } \\
(n=28)\end{array}$ \\
\hline Mean (SD) & $1022(233)$ & $846(191)$ & $11 \cdot 4(2 \cdot 7)$ & $9 \cdot 9(2 \cdot 2)$ & $340(71)$ & $277(58)$ \\
P10 & 658 & 633 & $8 \cdot 1$ & $7 \cdot 1$ & 252 & 208 \\
P25 & 891 & 687 & $9 \cdot 2$ & $8 \cdot 7$ & 270 & 241 \\
P50 & 1074 & 828 & $10 \cdot 9$ & $9 \cdot 6$ & 351 & 269 \\
Recomm. & 600 & 800 & 10 & 10 & 350 & 300 \\
\hline
\end{tabular}

\section{SPAIN}

\section{ELEMENT INTAKE DATA IN FOUR SPANISH AREAS}

Data on food intake were collected in the National Household Budget and Food and Nutrition Survey (1985). Foods providing $95 \%$ of the total energy intake were purchased in four Spanish regions: Galicia, Andalucia, Madrid and Valencia (Moreiras et al. 1993). The foods were purchased in markets, supermarkets, hypermarkets and grocery stores. All foods were analysed after homogenization, for $\mathrm{Cu}, \mathrm{Zn}, \mathrm{Fe}, \mathrm{Ca}, \mathrm{I}, \mathrm{Mg}, \mathrm{Pb}, \mathrm{Hg}$ and $\mathrm{Cd}$ (Moreiras et al. 1993; Anon. 1995; Cuadrado et al. 1995 a, b). The average intake data for the whole population are summarized in Table 28.

\section{ELEMENT INTAKE FROM A NATIONAL (SPANISH) TOTAL DIET}

Data for a national Spanish total diet were derived from the Spanish National Household Budget and Food and Nutrition Survey (1981). The estimated intake of $\mathrm{Zn}, \mathrm{Cr}, \mathrm{Pb}, \mathrm{Hg}$ and $\mathrm{Cd}$ were calculated from food composition tables. Results are presented in Table 29. 
Table 28. Intake of essential and toxic elements in average diets in four areas in Spain

\begin{tabular}{|c|c|c|c|c|}
\hline Element & Madrid & Valencia & Galicia & Andalucia \\
\hline $\mathrm{Ca}$ (mg) & 980 & 686 & 858 & 723 \\
\hline $\mathrm{Mg}(\mathrm{mg})$ & 302 & 293 & 379 & 388 \\
\hline $\mathrm{Fe}(\mathrm{mg})$ & $12 \cdot 9$ & $10 \cdot 8$ & $14 \cdot 7$ & 15.0 \\
\hline $\mathrm{Zn}(\mathrm{mg})$ & $12 \cdot 8$ & $10 \cdot 4$ & $11 \cdot 3$ & $9 \cdot 0$ \\
\hline $\mathrm{Cu}(\mathrm{mg})$ & $8 \cdot 6$ & 1.6 & $2 \cdot 1$ & $1 \cdot 7$ \\
\hline $\mathrm{I}(\mu \mathrm{g})$ & 82 & 43 & 43 & 76 \\
\hline $\mathrm{Pb}(\mu \mathrm{g})$ & 574 & 40 & 106 & 57 \\
\hline $\mathrm{Hg}(\mu \mathrm{g})$ & 9.8 & $4 \cdot 0$ & $8 \cdot 7$ & 12.8 \\
\hline $\mathrm{Cd}(\mu \mathrm{g})$ & 20 & 27 & 27 & 20 \\
\hline
\end{tabular}

Moreiras et al. 1993; Cuadrado et al. (1995a).

Table 29. Calculated intake of some trace elements in Spain and the food group with the highest \% contribution to the daily intake

\begin{tabular}{lcc}
\hline \hline Element & Intake & Contribution food group (\%) \\
\hline $\mathrm{Zn}(\mathrm{mg})$ & $11 \cdot 4$ & Cereals $38 \%$ \\
$\mathrm{Cr}(\mu \mathrm{g})$ & 99 & Vegetables $68 \%$ \\
$\mathrm{~Pb}(\mu \mathrm{g})$ & 82 & Vegetables $63 \%$ \\
$\mathrm{Hg}(\mu \mathrm{g})$ & 4 & Fish $100 \%$ \\
$\mathrm{Cd}(\mu \mathrm{g})$ & 55 & Vegetables $54 \%$ \\
\hline
\end{tabular}

Moreiras \& Cuadrado (1992).

Table 30. Intake of essential and toxic elements in total diets in Basque country of Spain, compared with the $R D A^{*}$ or the provisional tolerable daily intake (PTDI), calculated from the WHO/FAO Provisional Tolerable Weekly Intake

\begin{tabular}{cccccc}
\hline Element & Mean intake & P10 & P25 & P50 & $\begin{array}{c}\text { Mean intake } \\
\text { as \% of RDA }\end{array}$ \\
\hline $\mathrm{Fe}(\mathrm{mg} / \mathrm{d})$ & $11 \cdot 3$ & $10 \cdot 3$ & $10 \cdot 8$ & $11 \cdot 3$ & $113 \mathrm{M}, 63 \mathrm{~F}$ \\
$\mathrm{Zn}(\mathrm{mg} / \mathrm{d})$ & $11 \cdot 7$ & $10 \cdot 2$ & $10 \cdot 5$ & $11 \cdot 4$ & 77 \\
$\mathrm{Se}(\mu \mathrm{g} / \mathrm{d})$ & 79 & 67 & 72 & 80 & $113 \mathrm{M}, 147 \mathrm{~F}$ \\
& & & & Mean intake \\
Element & Mean intake & P50 & P75 & P90 & as \% of PTDI \\
$\mathrm{Pb}(\mu \mathrm{g} / \mathrm{d})$ & 40 & 36 & 40 & 66 & 8 \\
$\mathrm{Cd}(\mu \mathrm{g} / \mathrm{d})$ & 11 & 12 & 13 & 15 & 16 \\
$\mathrm{Hg}(\mu \mathrm{g} / \mathrm{d})$ & 18 & 19 & 20 & 23 & 36 \\
\hline
\end{tabular}

* RDA, recommended daily allowance: for Fe and Zn, Spanish RDA (Varela, 1981); for Se, US RDA (Food and Nutrition Board, 1989).

\section{ESTIMATED INTAKE OF ELEMENTS IN BASQUE COUNTRY}

The types and quantities of foods that comprise the average Basque total diet are based on the results of surveys carried out between 1988 and 1990 (Urieta et al. 1995). The food survey was executed on a representative sample of the adult population (25-60 years) and used a 24-h-recall interview and an individual food frequency questionnaire $(n=2348)$. 
Table 31. Food groups with the highest \% contribution to the daily intake of essential and toxic elements in the total diet of adults in the Basque country

\begin{tabular}{lllc}
\hline Element & \multicolumn{1}{c}{ Food groups } & Contribution (\%) \\
\hline & Fe & Meat & 21 \\
& Alcoholic beverages & 14 \\
& Bread & 13 \\
$\mathrm{Zn}$ & Meat & 40 \\
& Meat products & 10 \\
& Milk & 9 \\
& $\mathrm{Se}$ & Fish & 47 \\
& Meat & 26 \\
& Eggs & 9 \\
& Alcoholic beverages & 17 \\
& Fruits & 13 \\
& Bread & 23 \\
& $\mathrm{Cd}$ & Fish & 21 \\
& Potatoes & 14 \\
\hline \hline
\end{tabular}

Urieta et al. (1995).

Table 32. Estimated intakes of some essential and toxic elements in Tarragona Province in Spain

\begin{tabular}{lccccc}
\hline & $\begin{array}{c}\mathrm{Zn} \\
(\mathrm{mg} / \mathrm{d})\end{array}$ & $\begin{array}{c}\mathrm{Cu} \\
(\mathrm{mg} / \mathrm{d})\end{array}$ & $\begin{array}{c}\mathrm{Cr} \\
(\mu \mathrm{g} / \mathrm{d})\end{array}$ & $\begin{array}{c}\mathrm{Pb} \\
(\mu \mathrm{g} / \mathrm{d})\end{array}$ & $\begin{array}{c}\mathrm{Cd} \\
(\mu \mathrm{g} / \mathrm{d})\end{array}$ \\
\hline Total diet & 7.5 & 1.2 & 124 & 115 & 56 \\
Duplic. diet & 6.8 & $1 \cdot 1$ & 129 & nd & nd \\
\hline \hline
\end{tabular}

nd, not determined.

The major food items of the Basque total diet were combined into 16 food groups, after preparation and cooking. Each group was analysed for a number of essential and toxic elements. Results are presented in Table 30.

Table 31 gives the food groups with the highest $\%$ contribution of the various elements to the daily intake.

\section{ESTIMATED INTAKE OF TRACE ELEMENTS IN TARRAGONA PROVINCE}

In total 367 food samples were collected from various locations in the Tarragona Province of Spain. The foods were selected on the basis of a Household Food Consumption Survey in that Province carried out in 1985. An average total diet was calculated, the purchased foods were combined into 10 food groups and were analysed for $\mathrm{Zn}, \mathrm{Cu}, \mathrm{Cr}, \mathrm{Pb}$ and $\mathrm{Cd}$. Daily intakes were calculated from the results. In addition, duplicate weekly diets of 20 families were collected and analysed for $\mathrm{Zn}, \mathrm{Cu}$ and $\mathrm{Cr}$ (Table 32; Schuhmacher et al. 1991, 1993).

For $\mathrm{Zn}$, meat contributed most to the daily intake $(55 \%)$, followed by cereals $(17 \%)$ and fish/seafood $(7 \%)$. For $\mathrm{Cu}$, cereals appear to be the most important source $(30 \%)$, 
Table 33. Estimated daily intakes of essential and toxic trace elements in duplicate diets of university students in Valencia, Spain

\begin{tabular}{lcc}
\hline \hline Element & Mean daily intake & RDA* or PTDI $^{*}$ \\
\hline Fe (mg) & $15 \cdot 4$ & M 10, F 18 \\
Zn (mg) & $12 \cdot 1$ & 15 \\
$\mathrm{Cu}(\mathrm{mg})$ & $1 \cdot 25$ & $2-3$ \\
$\mathrm{Mn}(\mathrm{mg})$ & $2 \cdot 2$ & $2 \cdot 5-5$ \\
$\mathrm{~Pb}(\mu \mathrm{g})$ & 120 & 460 \\
$\mathrm{Cd}(\mu \mathrm{g})$ & 11 & 65 \\
\hline
\end{tabular}

* RDA, recommended daily allowance : for Fe and Zn, Spanish RDA (Varela, 1981); for Cu and Mn, US RDA (Food and Nutrition Board, 1989). PTD1, provisional tolerable daily intake.

Table 34. Intakes of mercury, lead and cadmium in some population groups in Sweden

\begin{tabular}{|c|c|c|c|c|c|c|}
\hline Element & Method & $\begin{array}{l}\text { No. of diets } \\
\text { or subjects }\end{array}$ & $\begin{array}{l}\text { Population } \\
\text { group }\end{array}$ & $\begin{array}{l}\text { Mean intake } \\
(\mu \mathrm{g} / \mathrm{d})\end{array}$ & $\begin{array}{l}\text { Range } \\
(\mu \mathrm{g} / \mathrm{d})\end{array}$ & Reference \\
\hline \multirow[t]{4}{*}{$\mathrm{Hg}$} & 24 h DD & 20 & Pensioners & 4 & $0 \cdot 6-19 \cdot 5$ & $\begin{array}{l}\text { Abdulla et al. } \\
1986 a\end{array}$ \\
\hline & $24 \mathrm{~h} \mathrm{DD}$ & 80 & $11-69 \mathrm{~F}$ & 7 & $1-24$ & $\begin{array}{l}\text { Abdulla et al. } \\
1989\end{array}$ \\
\hline & $7 \mathrm{~d}$ DD & 16 & $68-69 \mathrm{M}$ & $2 \cdot 1$ & $1 \cdot 1-3 \cdot 7$ & Schütz, $1979 b$ \\
\hline & $7 \mathrm{~d}$ DD & 18 & $68-69 \mathrm{~F}$ & $2 \cdot 1$ & 0.64 .5 & Schütz, $1979 b$ \\
\hline \multirow[t]{5}{*}{$\mathrm{Pb}$} & $24 \mathrm{~h} \mathrm{DD}$ & 20 & Pensioners & 36 & $6-86$ & $\begin{array}{l}\text { Abdulla et al. } \\
1986 a\end{array}$ \\
\hline & $24 \mathrm{~h}$ DD & 120 & $11-65 \mathrm{M} / \mathrm{F}$ & 45 & $8-90$ & $\begin{array}{l}\text { Abdulla et al. } \\
1989\end{array}$ \\
\hline & $7 \mathrm{~d}$ DD & 15 & $27-46 \mathrm{~F}$ & 26 & $13-40$ & Vahter et al. 1990 \\
\hline & $7 \mathrm{~d}$ DD & 13 & $68-69 \mathrm{M}$ & $35 / 10 \mathrm{MJ}$ & $11-74$ & Schütz, $1979 a$ \\
\hline & $7 \mathrm{~d}$ DD & 16 & $68-69 \mathrm{~F}$ & $29 / 10 \mathrm{MJ}$ & $6-39$ & Schütz, $1979 a$ \\
\hline \multirow[t]{5}{*}{$\mathrm{Cd}$} & 24 h DD & 20 & Pensioners & 12 & $4-35$ & $\begin{array}{l}\text { Abdulla et al. } \\
1986 a\end{array}$ \\
\hline & 24 h DD & 75 & $11-65 \mathrm{M} / \mathrm{F}$ & 18 & $5-45$ & $\begin{array}{l}\text { Abdulla et al. } \\
1989\end{array}$ \\
\hline & $7 \mathrm{~d} D D$ & 15 & $27-46 \mathrm{~F}$ & $8 \cdot 5$ & $5 \cdot 7-14$ & Vahter et al. 1990 \\
\hline & $7 \mathrm{~d}$ DD & 9 & $68-69 \mathrm{M}$ & $16 / 10 \mathrm{MJ}$ & 6-35 & Schütz, $1979 a$ \\
\hline & $7 \mathrm{~d}$ DD & 15 & $68-69 \mathrm{~F}$ & $16 / 10 \mathrm{MJ}$ & $4-29$ & Schütz, $1979 a$ \\
\hline
\end{tabular}

$\mathrm{DD}=$ Duplicate Diet $; \mathrm{F}=$ Females; $\mathrm{M}=$ Males

followed by pulses $(24 \%)$ and roots/tubers $(12 \%)$. The intake of chromium comes mainly from the food groups meat $(33 \%)$ and cereals $(28 \%)$. $\mathrm{Pb}$ is more evenly distributed; the highest $\%$ contribution comes from cereals $(17 \%)$, green vegetables $(17 \%)$ and fish/seafood $(15 \%)$. For $\mathrm{Cd}$, green vegetables contribute most to the daily intake $(26 \%)$, followed by fish/seafood $(21 \%)$ and fruits $(18 \%)$.

\section{ESTIMATED INTAKE OF TRACE ELEMENTS IN VALENCIA}

Duplicate diets and meals were collected from the university population in Valencia (Barberá et al. 1993). Various trace elements were analysed and the daily intake was calculated (Table 33). 


\section{SWEDEN}

From the submitted data, various studies based on duplicate diet analysis have been selected for this review (Schütz, 1979a, b; Abdulla, 1986; Abdulla et al. 1989; Vahter et al. 1990; Blanuša \& Jorhem, 1990).

The data on intake of toxic and essential elements are grouped by element in the following: Tables 34, 35. The numbers of analysed duplicate diets are indicated, the population group, the mean values and the range are presented for the toxic trace elements, but only the means for the essential elements.

\section{SWITZERLAND}

No national dietary intake surveys have been carried out in Switzerland; the data presented here summarize three recent studies in different population groups.

Adult daily diets (40) from restaurants, hospitals and army recruit school canteens were analysed for $\mathrm{Pb}, \mathrm{Hg}$ and $\mathrm{Cd}$ (Zimmerli et al. 1991). The daily intakes of these heavy metals were then calculated (Table 36). Mean and maximum intakes were all well below the WHO PTDI.

In the Euronut-SENECA study on Nutrition and the Elderly in Europe (Amorim Cruz, 1991; Schlettwein-Gsell et al. 1991), the dietary intakes of 361 70-75-year-old free-living elderly in three Swiss towns were measured using a one-month dietary history, checking portion sizes by weighing and subsequently calculating nutrient intakes using food composition tables. The daily intakes of $\mathrm{Ca}$ and $\mathrm{Fe}$ are given in Table 37. Median intakes of Fe and Ca were generally equal to or greater than the 1989 US RDA. Intakes of both nutrients were higher in men than in women because of greater overall energy intake of the former. Large proportions of women had low energy intakes; this was associated with low intakes of micronutrients, including $\mathrm{Ca}$ and $\mathrm{Fe}$. On the other hand, the dietary nutrient density was greater for women and for those elderly having low energy intakes. This was achieved through wiser food choice. No significant impairment of nutritional status was associated with low energy intake owing probably, at least in part, to the higher nutrient density of the diet.

The daily intakes of $\mathrm{Ca}, \mathrm{Mg}$ and $\mathrm{Fe}$ were measured for 63 primary and secondary school students age 7-16 years (Seidel, 1992). Results are presented in Table 37. Mean intakes of $\mathrm{Ca}$ and $\mathrm{Mg}$ were somewhat low compared to the 1989 US RDA, especially for the older age groups. Mean $\mathrm{Fe}$ intakes were similar to recommended levels.

\section{GENERAL DISCUSSION}

The aim of this paper was to collect intake data for an agreed number of essential and toxic elements among various population groups in European, particularly EU, countries.

As this paper is not an extended literature study, but is based on the data which were made available by the FLAIR Concerted Action No. 10 participants, it does not cover all intake studies which have been carried out in the past 10 years. From the information obtained, we have preferentially selected those data which are based on any form of food analysis, rather than solely on food tables. However, if data based on duplicate diet analysis or analysis of individual food items were not available from a certain country we have included other data in order to obtain some insight into element intake in that country. 
Table 35. Daily intakes of essential elements in some population groups in Sweden

\begin{tabular}{|c|c|c|c|c|c|c|}
\hline Element & Method & $\begin{array}{l}\text { No. of diets } \\
\text { or subjects }\end{array}$ & $\begin{array}{l}\text { Population } \\
\text { group }\end{array}$ & $\begin{array}{l}\text { Mean } \\
\text { intake }\end{array}$ & $\mathrm{RDA}^{\dagger}$ & Reference \\
\hline \multirow[t]{9}{*}{$\mathrm{Fe}(\mathrm{mg})$} & 24 h DD & 20 & $25-60 \mathrm{M} / \mathrm{F}$ & 13 & $10 \mathrm{M} / 18 \mathrm{~F}$ & Abdulla $e t$ al. $1986 a$ \\
\hline & $24 \mathrm{~h} \mathrm{DD}$ & 37 & Pensioners & 11 & $10 \mathrm{M} / 18 \mathrm{~F}$ & Abdulla et al. $1986 a$ \\
\hline & $24 \mathrm{~h} \mathrm{DD}$ & 60 & $30-79 \mathrm{~F}$ & 15 & 18 & Abdulla et al. $1986 a$ \\
\hline & $24 \mathrm{~h} \mathrm{DD}$ & 6 & 49-55 veg. & $16 \cdot 5$ & $10 \mathrm{M} / 18 \mathrm{~F}$ & Abdulla et al. $1986 a$ \\
\hline & $24 \mathrm{~h} \mathrm{DD}$ & 6 & 49-52 lact. & 14 & $10 \mathrm{M} / 18 \mathrm{~F}$ & Abdulla et al. $1986 a$ \\
\hline & $24 \mathrm{~h}$ DD & 15 & $23-53 \mathrm{~F}$ & 16.9 & 18 & $\begin{array}{l}\text { Blanuša \& Jorhem, } \\
1990\end{array}$ \\
\hline & $24 \mathrm{~h} \mathrm{DD}$ & $*$ & $11-14 \mathrm{M} / \mathrm{F}$ & 17 & $12 \mathrm{M} / 18 \mathrm{~F}$ & Abdulla et al. 1989 \\
\hline & 24 h DD & $*$ & $20-55 \mathrm{M} / \mathrm{F}$ & 12 & $10 \mathrm{M} / 18 \mathrm{~F}$ & Abdulla et al. 1989 \\
\hline & $24 \mathrm{~h} \mathrm{DD}$ & $*$ & $>65 \mathrm{M} / \mathrm{F}$ & 11 & 10 & Abdulla et al. 1989 \\
\hline \multirow[t]{10}{*}{$\mathrm{Zn}(\mathrm{mg})$} & $7 \mathrm{~d}$ DD & 17 & $67-69 \mathrm{M}$ & $8 \cdot 2$ & $15-20$ & Abdulla et al. $1986 d$ \\
\hline & $7 \mathrm{~d}$ DD & 20 & $67-69 \mathrm{~F}$ & $7 \cdot 2$ & $15-20$ & Abdulla et al. $1986 d$ \\
\hline & $24 \mathrm{~h} \mathrm{DD}$ & 20 & $25-60 \mathrm{M} / \mathrm{F}$ & 8 & $15-20$ & Abdulla et al. $1986 a$ \\
\hline & $24 \mathrm{~h} \mathrm{DD}$ & 37 & Pensioners & $7 \cdot 5$ & $15-20$ & Abdulla et al. $1986 a$ \\
\hline & $24 \mathrm{~h} \mathrm{DD}$ & 60 & $30-79 \mathrm{~F}$ & 8 & $15-20$ & Abdulla et al. $1986 a$ \\
\hline & 24 h DD & 6 & 49-55 veg. & 12 & $15-20$ & Abdulla et al. $1986 a$ \\
\hline & $24 \mathrm{~h} \mathrm{DD}$ & 6 & 49-52 lact. & 11 & $15-20$ & Abdulla et al. $1986 a$ \\
\hline & $24 \mathrm{~h} \mathrm{DD}$ & 15 & $23-53 \mathrm{~F}$ & $9 \cdot 3$ & 15 & $\begin{array}{l}\text { Blanuša \& Jorhem, } \\
1990\end{array}$ \\
\hline & $24 \mathrm{~h} \mathrm{DD}$ & * & $11-14 \mathrm{M} / \mathrm{F}$ & $8 \cdot 2$ & $12-15$ & Abdulla et al. 1989 \\
\hline & 24 h DD & $*$ & $20-55 \mathrm{M} / \mathrm{F}$ & $7 \cdot 8$ & $15-20$ & Abdulla et al. 1989 \\
\hline \multirow[t]{10}{*}{$\mathrm{Mg}(\mathrm{mg})$} & $7 \mathrm{~d}$ DD & 17 & $67-69 \mathrm{M}$ & 210 & $300-400$ & Jägerstadt et al. 1986 \\
\hline & $7 \mathrm{~d}$ DD & 19 & $67-69 \mathrm{~F}$ & 170 & $300-400$ & Jägerstadt et al. 1986 \\
\hline & 24 h DD & 20 & $25-60 \mathrm{M} / \mathrm{F}$ & 200 & $300-400$ & Abdulla et al. 1986 a \\
\hline & 24 h DD & 37 & Pensioners & 200 & $300-400$ & Abdulla et al. $1986 a$ \\
\hline & $24 \mathrm{~h}$ DD & 60 & $30-79 \mathrm{~F}$ & 250 & $300-400$ & Abdulla et al. $1986 a$ \\
\hline & $24 \mathrm{~h} \mathrm{DD}$ & 6 & $49-55$ veg. & 550 & $300-400$ & Abdulla et al. 1986a \\
\hline & $24 \mathrm{~h} \mathrm{DD}$ & 6 & 49-52 lact. & 450 & $300-400$ & Abdulla et al. $1986 a$ \\
\hline & $24 \mathrm{~h} \mathrm{DD}$ & $*$ & $11-14 \mathrm{M} / \mathrm{F}$ & 267 & $300-350$ & Abdulla et al. 1989 \\
\hline & 24 h DD & $*$ & $20-55 \mathrm{M} / \mathrm{F}$ & 243 & $300-400$ & Abdulla et al. 1989 \\
\hline & $24 \mathrm{~h} \mathrm{DD}$ & $*$ & $>65 \mathrm{M} / \mathrm{F}$ & 219 & $300-400$ & Abdulla et al. 1989 \\
\hline \multirow[t]{11}{*}{$\mathrm{Ca}(\mathrm{mg})$} & $7 \mathrm{~d}$ DD & 17 & $67-69 \mathrm{M}$ & 726 & $400-800$ & Jägerstadt et al. 1986 \\
\hline & $7 \mathrm{~d}$ DD & 20 & $67-69 \mathrm{~F}$ & 610 & $400-800$ & Jägerstadt et al. 1986 \\
\hline & $24 \mathrm{~h} \mathrm{DD}$ & 20 & $25-60 \mathrm{M} / \mathrm{F}$ & 700 & $400-800$ & Abdulla et al. $1986 a$ \\
\hline & $24 \mathrm{~h} \mathrm{DD}$ & 37 & Pensioners & 700 & $400-800$ & Abdulla et al. $1986 a$ \\
\hline & $24 \mathrm{~h}$ DD & 60 & $30-79 \mathrm{~F}$ & 550 & $400-800$ & Abdulla et al. $1986 a$ \\
\hline & $24 \mathrm{~h} \mathrm{DD}$ & 6 & $49-55$ veg. & 600 & $400-800$ & Abdulla et al. $1986 a$ \\
\hline & $24 \mathrm{~h} \mathrm{DD}$ & 6 & 49-52 lact. & 900 & $400-800$ & Abdulla et al. $1986 a$ \\
\hline & $24 \mathrm{~h} \mathrm{DD}$ & 15 & $23-53 \mathrm{~F}$ & 845 & $400-800$ & $\begin{array}{l}\text { Blanuša \& Jorhem, } \\
1990\end{array}$ \\
\hline & $24 \mathrm{~h} \mathrm{DD}$ & $*$ & $11-14 \mathrm{M} / \mathrm{F}$ & 1200 & 800 & Abdulla et al. 1989 \\
\hline & $24 \mathrm{~h} \mathrm{DD}$ & $*$ & $20-55 \mathrm{M} / \mathrm{F}$ & 800 & $400-800$ & Abdulla et al. 1989 \\
\hline & $24 \mathrm{~h} \mathrm{DD}$ & $*$ & $>65 \mathrm{M} / \mathrm{F}$ & 720 & $400-800$ & Abdulla et al. 1989 \\
\hline \multirow[t]{11}{*}{$\mathrm{Cu}(\mathrm{mg})$} & $7 \mathrm{~d}$ DD & 17 & $67-69 \mathrm{M}$ & $1 \cdot 25$ & $2-2 \cdot 5$ & $\begin{array}{l}\text { Abdulla \& Svensson, } \\
1986\end{array}$ \\
\hline & $7 \mathrm{~d} D D$ & 20 & $67-69 \mathrm{~F}$ & 0.9 & $2-2 \cdot 5$ & $\begin{array}{l}\text { Abdulla \& Svensson, } \\
1986\end{array}$ \\
\hline & $24 \mathrm{~h} \mathrm{DD}$ & 20 & $25-60 \mathrm{M} / \mathrm{F}$ & $1 \cdot 5$ & $2-2 \cdot 5$ & Abdulla et al. 1986a \\
\hline & $24 \mathrm{~h} \mathrm{DD}$ & 37 & Pensioners & 1 & $2-2 \cdot 5$ & Abdulla et al. $1986 a$ \\
\hline & $24 \mathrm{~h}$ DD & 60 & $30-79 \mathrm{~F}$ & 1.5 & $2-2 \cdot 5$ & Abdulla et al. $1986 a$ \\
\hline & $24 \mathrm{~h} \mathrm{DD}$ & 6 & $49-55$ veg. & $3 \cdot 5$ & $2-2 \cdot 5$ & Abdulla et al. $1986 a$ \\
\hline & $24 \mathrm{~h}$ DD & 6 & $49-52$ lact. & 2 & $2-2 \cdot 5$ & Abdulla et al. $1986 a$ \\
\hline & 24 h DD & 15 & $23-53 \mathrm{~F}$ & 1.06 & $2-2 \cdot 5$ & $\begin{array}{l}\text { Blanuša \& Jorhem, } \\
1990\end{array}$ \\
\hline & $24 \mathrm{~h} \mathrm{DD}$ & * & $11-14 \mathrm{M} / \mathrm{F}$ & 1.46 & - & Abdulla et al. 1989 \\
\hline & $24 \mathrm{~h} \mathrm{DD}$ & $*$ & $20-55 \mathrm{M} / \mathrm{F}$ & $1 \cdot 33$ & $2-2 \cdot 5$ & Abdulla et al. 1989 \\
\hline & $24 \mathrm{~h} \mathrm{DD}$ & $*$ & $>65 \mathrm{M} / \mathrm{F}$ & $1 \cdot 27$ & $2-2 \cdot 5$ & Abdulla et al. 1989 \\
\hline
\end{tabular}


Table 35 (cont.)

\begin{tabular}{|c|c|c|c|c|c|c|}
\hline Element & Method & $\begin{array}{l}\text { No. of diets } \\
\text { or subjects }\end{array}$ & $\begin{array}{l}\text { Population } \\
\text { group }\end{array}$ & $\begin{array}{l}\text { Mean } \\
\text { intake }\end{array}$ & RDA $†$ & Reference \\
\hline \multirow[t]{4}{*}{$\operatorname{Cr}(\mu \mathrm{g})$} & $7 \mathrm{~d} D \mathrm{DD}$ & 17 & $67-69 \mathrm{M}$ & 229 & $50-200$ & $\begin{array}{l}\text { Abdulla \& Svensson, } \\
1986\end{array}$ \\
\hline & $7 \mathrm{~d} \mathrm{DD}$ & 20 & $67-69 \mathrm{~F}$ & 145 & $50-200$ & $\begin{array}{l}\text { Abdulla \& Svensson, } \\
1986\end{array}$ \\
\hline & $24 \mathrm{~h} \mathrm{DD}$ & 37 & Pensioners & 182 & $50-200$ & Abdulla et al. $1986 a$ \\
\hline & 24 h DD & 60 & $11->65$ & 160 & $50-200$ & Abdulla et al. 1989 \\
\hline \multirow[t]{10}{*}{ Se $(\mu \mathrm{g})$} & $7 \mathrm{~d}$ DD & 9 & $67-69 \mathrm{M}$ & 24 & 50 & Abdulla et al. $1986 c$ \\
\hline & $7 \mathrm{~d} \mathrm{DD}$ & 11 & $67-69 \mathrm{~F}$ & 24 & 50 & Abdulla et al. $1986 \mathrm{c}$ \\
\hline & $24 \mathrm{~h} \mathrm{DD}$ & 20 & $25-60 \mathrm{M} / \mathrm{F}$ & 28 & 50 & Abdulla et al. $1986 a$ \\
\hline & 24 h DD & 37 & Pensioners & 35 & 50 & Abdulla et al. $1986 a$ \\
\hline & 24 h DD & 60 & $30-70 \mathrm{~F}$ & 26 & 50 & Abdulla et al. $1986 a$ \\
\hline & $24 \mathrm{~h} \mathrm{DD}$ & 6 & 49-55 veg. & 10 & 50 & Abdulla et al. $1986 a$ \\
\hline & 24 h DD & 6 & 49-52 lact. & 64 & 50 & Abdulla et al. $1986 a$ \\
\hline & 24 h DD & * & $11-14 \mathrm{M} / \mathrm{F}$ & 32 & 40 & Abdulla et al. 1989 \\
\hline & 24 h DD & * & $20-55 \mathrm{M} / \mathrm{F}$ & 32 & 50 & Abdulla et al. 1989 \\
\hline & $24 \mathrm{~h} \mathrm{DD}$ & * & $>65 \mathrm{M} / \mathrm{F}$ & 32 & 50 & Abdulla et al. 1989 \\
\hline \multirow{4}{*}{ I $(\mu \mathrm{g})$} & $7 \mathrm{dDD}$ & 16 & $67-69 \mathrm{M}$ & 318 & 150 & Abdulla et al. $1986 b$ \\
\hline & $7 \mathrm{~d}$ DD & 19 & $67-69 \mathrm{~F}$ & 246 & 150 & Abdulla et al. $1986 b$ \\
\hline & 24 h DD & 37 & Pensioners & 282 & 150 & Abdulla et al. $1986 a$ \\
\hline & $24 \mathrm{~h} \mathrm{DD}$ & 100 & $11->65 \mathrm{M} / \mathrm{F}$ & 290 & 150 & Abdulla et al. $1986 a$ \\
\hline $\mathrm{Mn}(\mathrm{mg})$ & $24 \mathrm{~h} \mathrm{DD}$ & 15 & $23-53 \mathrm{~F}$ & 3.6 & $2 \cdot 5-5$ & Abdulla et al. 1989 \\
\hline
\end{tabular}

* Number of diets are not specified; in total 900 diets of a group of children (11-14 years), adults (20-55 years) and elderly people ( $>65$ years) were analysed.

+ RDA: Nordic Committee on Foods (1989).

DD = Duplicate Diet.

$\mathrm{F}=$ Females; $\mathbf{M}=$ Males; veg. = Vegans, lact. = lactovegetarians.

Table 36. Lead, mercury and cadmium in daily adult diets from restaurants, hospitals and army recruit school canteens in Switzerland

\begin{tabular}{|c|c|c|c|c|}
\hline Element & Mean intake & Range & PTDI & PTDI $(\%)$ \\
\hline $\begin{array}{l}\mathrm{Pb}(\mu \mathrm{g} / \mathrm{d}) \\
\mathrm{Hg}(\mu \mathrm{g} / \mathrm{d}) \\
\mathrm{Cd}(\mu \mathrm{g} / \mathrm{d})\end{array}$ & $\begin{array}{r}25 \\
<5 \\
12\end{array}$ & $\begin{array}{c}4-66 \\
<5-6 \\
5-24\end{array}$ & $\begin{array}{r}430 \\
43 \\
60\end{array}$ & $\begin{array}{r}6 \\
<12 \\
20\end{array}$ \\
\hline
\end{tabular}

PTDI, Provisional Tolerable Daily Intake, derived from the WHO Provisional Tolerable Weekly Intake.

As was mentioned in the introduction, data have been collected by applying different methods in different countries. There is always a risk that intake data are over- or underreported. Most methods tend to underestimate intakes, which has clearly been shown for the duplicate diet technique. One way to assess the degree of under-reporting is to compare reported energy intakes with estimates of plausible energy requirements based on body weight and physical activity level. Measurement of 24-h urinary nitrogen excretion can be used to validate reported protein intake. Most trace elements are relatively evenly distributed in foods so that the nutrient density (amount of an element in relation to energy content) can be used to compare the intake of different groups. In future studies of trace element intakes it is recommended that available validation methods are included, that body weights of participating subjects are given and that total energy and protein intakes are reported together with the trace element intake data. 
Table 37. Intakes of calcium and iron in elderly people, 70-75 years of age, from 3 towns in Switzerland

\begin{tabular}{|c|c|c|c|c|c|c|c|c|c|}
\hline \multirow[b]{2}{*}{ Town } & \multirow[b]{2}{*}{ Sex } & \multicolumn{4}{|c|}{$\mathrm{Ca}(\mathrm{mg} / \mathrm{d})$} & \multicolumn{4}{|c|}{$\mathrm{Fe}(\mathrm{mg} / \mathrm{d})$} \\
\hline & & Mean & P10 & P50 & P90 & Mean & P10 & P50 & P90 \\
\hline \multirow[t]{2}{*}{ Burgdorf } & $\begin{array}{l}\text { Male } \\
\quad(n=30)\end{array}$ & 1248 & 784 & 1101 & 1769 & 13 & $9 \cdot 1$ & 13.6 & $16 \cdot 2$ \\
\hline & $\begin{array}{l}\text { Female } \\
\quad(n=30)\end{array}$ & 1022 & 585 & 1000 & 1676 & 11 & 8.0 & $10 \cdot 0$ & $13 \cdot 2$ \\
\hline \multirow[t]{2}{*}{ Yverdon } & $\begin{array}{l}\text { Male* }^{*}(n=117)\end{array}$ & 932 & 621 & 996 & 1493 & 12 & 8.9 & $12 \cdot 3$ & $15 \cdot 7$ \\
\hline & $\begin{array}{l}\text { Female* } \\
\quad(n=124)\end{array}$ & 853 & 506 & 802 & 1243 & 10 & 688 & $10 \cdot 0$ & $12 \cdot 7$ \\
\hline \multirow[t]{2}{*}{ Bellinzona } & $\begin{array}{l}\text { Male } \\
\quad(n=30)\end{array}$ & 1105 & 778 & 1036 & 1575 & 15 & $10 \cdot 2$ & $15 \cdot 0$ & $20 \cdot 6$ \\
\hline & $\begin{array}{l}\text { Female } \\
\qquad(n=30)\end{array}$ & 966 & 561 & 900 & 1456 & 13 & $9 \cdot 1$ & $13 \cdot 0$ & $19 \cdot 1$ \\
\hline
\end{tabular}

* For mean values, only 74-75-year-old subjects were included (both sexes $n=31$ ).

Table 38. Dietary intakes of calcium, magnesium and iron among Swiss school children $(n=63)$

Values are means $\pm \mathrm{sD}$

\begin{tabular}{lccc}
\hline Age/gender & $\mathrm{Ca}(\mathrm{mg} / \mathrm{d})$ & $\mathrm{Mg}(\mathrm{mg} / \mathrm{d})$ & $\mathrm{Fe}(\mathrm{mg} / \mathrm{d})$ \\
\hline $7-9$ year males & $678 \pm 224$ & $214 \pm 53$ & $9 \cdot 5 \pm 1 \cdot 9$ \\
$7-9$ year females & $748 \pm 173$ & $217 \pm 35$ & $9 \cdot 5 \pm 1 \cdot 8$ \\
$10-12$ year males & $753 \pm 288$ & $193 \pm 41$ & $9 \cdot 9 \pm 1 \cdot 9$ \\
$10-12$ year females & $775 \pm 219$ & $239 \pm 106$ & $10 \cdot 2 \pm 2 \cdot 7$ \\
$13-14$ year males & $1143 \pm 490$ & $242 \pm 76$ & $11 \cdot 3 \pm 3 \cdot 0$ \\
$13-14$ year females & $786 \pm 227$ & $207 \pm 42$ & $10 \cdot 7 \pm 1 \cdot 9$ \\
$15-16$ year males & $810 \pm 161$ & $254 \pm 54$ & $12 \cdot 2 \pm 1 \cdot 2$ \\
$15-16$ year females & $640 \pm 147$ & $188 \pm 50$ & $9 \cdot 7 \pm 2 \cdot 3$ \\
\hline
\end{tabular}

However it is still possible to derive some general conclusions from the information presented in this paper. Nevertheless, the following considerations should be taken into account when interpreting the results:

The use of RDA for evaluating intake data must be treated with caution. In addition to the fact that RDA for a certain element may differ between countries, the significance of intake values below the RDA should be discussed in the light of the importance of the RDA. A mean intake below the RDA for a defined population group does not necessarily mean that the conclusion '(marginally) deficient' is applicable. Even the cutoff point of $80 \%$ of the RDA (often used for evaluating intake data) is debatable.

Furthermore, for some elements ( $\mathrm{Se}, \mathrm{Cu}$ ), only safe and adequate intakes have been formulated, indicating uncertainty as to requirements.

If the intake data clearly show that in a certain population group a high percentage of that group has an intake (e.g. of $\mathrm{Cu}$ ) that is much lower than the RDA, the question should be asked whether this is reflected by low body stores. Furthermore, low intakes also demonstrate the necessity for checking the intake findings against some form of status assessment. A thorough discussion of these factors falls beyond the scope of this paper, but a reasonably extensive literature is available on interpretation of intake data. 
The following overall picture emerges from the intake data presented in this paper. It can be concluded that little concern need be expressed regarding the mean intake of toxic trace elements. However, in some cases (when maximum values are reported) some intakes are above the ADI. As only a chronically high intake of harmful elements may cause health problems, a single observation of an intake above the ADI ( $24 \mathrm{~h}$ duplicate diet) does not necessarily mean that real health problems are involved.

Regarding the essential elements, the intakes of $\mathrm{Cu}, \mathrm{Fe}$ and $\mathrm{Se}$ appear to be inadequate in several countries. For $\mathrm{Cu}$ and $\mathrm{Se}$ the issue of requirements should be taken into account in discussing the significance of the reported low intakes. It seems that for $\mathrm{Fe}$ an assessment of the $\mathrm{Fe}$ status of low-intake population groups is desirable and also feasible as good status parameters exist for $\mathrm{Fe}$. Status parameters for $\mathrm{Se}$ and $\mathrm{Cu}$ are discussed in the recent FLAIR Concerted Action 10 publication in the International Journal for Vitamin and Nutrition Research (vol. 10, no. 4, 1993). The conclusion for $\mathrm{Cu}$ is that good indices of $\mathrm{Cu}$ status have yet to be found. For Se, some parameters may be suitable depending on the Se status of the population.

The general conclusions from the intake data which were made available by the FLAIR Concerted Action No. 10 participants are:

- The intake of toxic elements among population groups in the respective EU countries does not seem to be a major problem.

- The intake of essential elements, particularly of $\mathrm{Fe}, \mathrm{Cu}$ and $\mathrm{Se}$, appears to be inadequate (when compared to the RDA) in many population groups.

- The significance of the findings should be evaluated by further studies in which the status of a selected number of elements in defined population groups is assessed.

- Harmonization and standardization with respect to intake assessment in different countries is clearly very desirable.

\section{REFERENCES}

Abdulla, M. (Editor) (1986). Inorganic Chemical Elements in Prepared Meals in Sweden: Food Collection and Analytical Techniques, Concentration in Body Compartments, Metabolic Aspects and Public Health/Clinical Significance. Lund, Sweden: University of Lund.

Abdulla, M., Bebbehani, A. \& Dashi, H. (1989). Dietary intake and bioavailability of trace elements. Biological Trace Element Research 21, 173-178.

Abdulla, M., Jägerstadt, M., Kolár, K., Nordén, Å., Schütz, A. \& Svensson, S. (1986a). Essential and toxic inorganic elements in prepared meals - 24-hour dietary sampling employing the duplicate portion technique. In Trace Element Analytical Chemistry in Medicine and Biology, vol. 2, pp. 75-86. [P. Brätter and P. Schrammel, editors]. Berlin: de Gruyter.

Abdulla, M., Jägerstadt, M., Melander, A., Nordén, Å., Svensson, S. \& Wåhlin, E. (1986b). Iodine. In Inorganic Chemical Elements in Prepared Meals in Sweden, pp. 185-190. [M. Abdulla, editor]. Lund, Sweden: University of Lund.

Abdulla, M., Kolár, K. \& Svensson, S. (1986c). Selenium. In Inorganic Chemical Elements in Prepared Meals in Sweden, pp. 181-184. [M. Abdulla, editor]. Lund, Sweden: University of Lund.

Abdulla, M. \& Svensson, S. (1986). Copper. In Inorganic Chemical Elements in Prepared Meals in Sweden, pp. 172-175 [M. Abdulla, editor]. Lund, Sweden: University of Lund.

Abdulla, M., Svensson, S. \& Nordén, A. (1986d). Zinc. In Inorganic Chemical Elements in Prepared Meals in Sweden, pp. 168-171 [M. Abdulla, editor]. Lund, Sweden: University of Lund.

Amorim Cruz, J. A., Moreiras-Varela, O., van Staveren, W. A., Trichopoulou, A. \& Roszkowski, W. (1991). Intake of vitamins and minerals. Euronut SENECA Study on Nutrition and the Elderly in Europe. European Journal of Clinical Nutrition 45, Supplement 3, 121-138.

Anon. (1994). NEVO tabel. [Dutch nutrient database 1993-1994]. The Hague: Dutch Bureau for Nutrition Education. 
Anon. (1995). [Data relevant to the Programme for Total Diet (1993).] Dirección de Salud Pública del Departamento de Sanidad del Gobierno Vasco (In the Press).

Barberá, R., Farré, R. \& Mesado, D. (1993). Oral intake of cadmium, cobalt, copper, iron, lead, nickel, manganese and zinc in the University student's diet. Nahrung 3, 241-245.

Blanuša, M. \& Jorhem, L. (1991). Dietary intake of some essential elements in Sweden and Yugoslavia. In Trace Elements in Man and Animals 7 (International Symposium, Dubrovnik, 1990) [B Momčilović, editor]. Zagreb: Institute for Medical Research and Occupational Health, University of Zagreb.

Bro, S., Sandström, B. \& Heydorn, K. (1990). Intake of essential and toxic trace elements in a random sample of Danish men as determined by the duplicate portion sampling technique. Journal of Trace Elements and Electrolytes in Health and Disease 4, 147-155.

Brussaard, J. H., Schneijder, P., van Aken, A. M. M. A. M.., van Dokkum, W. \& de Vos, R. H. (1994). Dietary intake of food contaminants in the Netherlands. Input from TNO Total Diet Study 1988-1989. 1. Cadmium, lead, organochlorine compounds, nitrate and malathion. TNO Report no. V 93.567. Zeist: TNO-Nutrition and Food Research.

Buchet, J. P., Lauwerys, R., Vandevoorde, A. \& Pycke, J. M. (1981). [Evaluation of the average amount of cadmium, lead, manganese, copper, chromium, mercury, calcium, zinc and arsenic ingested daily by adults in Belgium.] Archives Belges de Médecine Sociale, Hygiène, Médecine du Travail et Médecine Légale 39, 465-480.

Bull, N. L. (1985). Dietary habits of 15 to 25-year-olds. Human Nutrition: Applied Nutrition 39A (Supplement) $1-68$.

Cuadrado, C., Kumpulainen, J. \& Moreiras, O. (1995a). [Lead, cadmium and mercury contents in average Spanish market basket diets from Galicia, Valencia, Andalucia and Madrid (MS no. 294). Food Additives and Contaminants 12, 107-118.

Cuadrado, C., Kumpulainen, J. \& Moreiras, O. (1995b). Contaminants and nutrients in total diets in Spain. European Journal of Clinical Nutrition (In the Press).

Department of Health (1989). The Diets of British Schoolchildren (Report on Health and Social Subjects no. 36). London: HMSO.

Department of Health (1991). Dietary Reference Values for Food Energy and Nutrients for the United Kingdom. London: HMSO.

DGE (Deutsche Gesellschaft für Ernährung) (1988). [Food and Nutrition Survey 1988.] pp. 75-76. Frankfurt: DGE.

DGE (Deutsche Gesellschaft für Ernährung) (1992). [Food and Nutrition Survey 1992], p. 43. Frankfurt: DGE.

Favier, A. \& Lamand, M. (1992). [Intakes of minerals: minor elements.] In Apports Nutritionnels Conseilles pour la Population Française, pp. 41-49 [H. Dupin, J. Abraham and L. Giachetti, editors]. Paris: Technique et Documentation, Lavoisier.

Food and Nutrition Board (1989). Recommended Dietary Allowances, 10th revised edition. Washington, DC: National Academy Press.

Frank, G. (Editor) (1991). Die Nationale Verzehrsstudie. In Materialen zur Gesundheitsforschung, vol. 18. Bremerhaven: Wirtschaftsverlag NW.

Freudenheim, J. L., Krogh, V., D'Amicis, A., Scaccini, C., Sette, S., Ferro-Luzzi, A. \& Trevisan, M. (1993). Food sources of nutrients in the diet of Italian elderly. 2. Micronutrients. International Journal of Epidemiology 22, 869-877.

Frost Anderson, L., Nes, M., Lillegaard, I. T., Sandstad, B., Bjørneboe, G.-E. Aa. \& Drevon, C. A. (1995a). Evaluation of a quantitative food frequency questionnaire used in a group of Norwegian adolescents. European Journal of Clinical Nutrition. (In the Press).

Frost Anderson, L., Nes, M., Sandstad, B., Bjørneboe, G.-E. Aa. \& Drevon, C. A. (1995b). Dietary intake in Norwegian adolescents. European Journal of Clinical Nutrition. (In the Press).

Gregory, J. R., Collins, D. L., Davies, P. S. W., Hughes, J. M. \& Clarke, P. C. (1995). National Diet and Nutrition Survey: children aged 1.5-4.5 years. In Report of the Diet and Nutrition Survey, vol. 1. London: HMSO.

Gregory, J., Foster, K., Tyler, H. \& Wiseman, M. (1990). The Dietary and Nutritional Survey of British Adults. London: HMSO

Haraldsdóttir, J., Holm, L., Højmark Jensen, J. \& Møller, A. (1986). [Dietary habits of Danes in 1985. 1. Main results.] Søborg: Levnedsmiddelstyrelsen (Publikation no. 136).

Hendrix, P., van Cauwenbergh, R., Robberecht, H. J. \& Deelstra, H. A. (1995). Daily dietary calcium and magnesium intake in Belgium using duplicate portion sampling. Zeitschrifi für Lebensmittel-Untersuchung und -Forschung 200. (In the Press).

Heseker, H., Adolf, T., Eberhardt, W., Hartmann, S., Herwig, A., Kübler, W., Matiaske, B., Moch, K. J., Schneider, R. \& Zipp, A. (1992). [Food and nutrient intakes of adults in the German Federal Republic]. In VERA-Schriftenreihe, vol. 3, pp. 188-189 [W. Kübler, H. J. Anders, W. Heeschen and M. Kohlmeier, editors]. Niederkleen: Fleck Verlag.

INDI (Irish Nutrition and Dietetic Institute) (1990). Irish National Nutrition Survey 1990. Dublin: INDI.

Jägerstadt, M., Abdulla, M., Svensson, S. \& Nordén, A. (1986). Calcium. In Inorganic Chemical Elements in Prepared Meals in Sweden, pp. 148-152 [M. Abdulla, editor]. Lund, Sweden: University of Lund.

Lamand, M., Tressol, J. C. \& Bellanger, J. (1994). The mineral and trace element composition in French food items and intake levels in France. Journal of Trace Elements and Electrolytes in Health and Disease 8, $195-202$. 
McCance, R. A. \& Widdowson, E. M. (1991). The Composition of Foods, 5th edn, and supplements [B. Holland, A. A. Welch, I. D. Unwin, D. H. Buss, A. A. Paul and D. A. T. Southgate, editors]. Letchworth: Royal Society of Chemistry.

Mills, A. \& Tyler, H. (1992). Food and Nutrient Intakes of British Infants aged 6-12 Months. London: HMSO. MAFF (Ministry of Agriculture, Fisheries and Food) (1993). National Food Survey 1992. London: HMSO.

MAFF (Ministry of Agriculture, Fisheries and Food) (1944a). National Food Survey 1993. London: HMSO.

MAFF (Ministry of Agriculture, Fisheries and Food) (1994b). The Dietary and Nutritional Survey of British Adults. Further Analysis. London: HMSO.

Moreiras, O. \& Cuadrado, C. (1992). Theoretical study of the intake of trace elements (nutrients and contaminants) via total diet in some geographical areas of Spain. Biological Trace Element Research 32, 93-103.

Moreiras, O., Cuadrado, C., Lamand, M. \& Tressol, J. C. (1993). The adequacy of essential minerals intake in four areas of Spain as assessed by direct analysis and a data base. Nutrition Research 13, 851-861.

Nes, M., Lund-Larsen, K., Trygg, K., Sandstad, B., Høvik, H. O. \& Pedersen, J. I. (1993). Nutrition and the elderly in Europe: low prevalence of obesity and biochemical deficiencies in Norwegian subjects. Age and Nutrition 4, 72-81.

Netherlands Food and Nutrition Council (1992). Recommended Dietary Allowances 1989 in the Netherlands: summary. The Hague: NFNC.

Nordic Committee on Foods (1989). Nordic Nutrition Recommendations 2. Copenhagen: Nordic Council of Ministers.

Peattie, M. E., Buss, D. H., Lindsay, D. G. \& Smart, G. A. (1983). Reorganisation of the British Total Diet Study for monitoring food constituents from 1981. Food and Chemical Toxicology 21, 503-507.

Robberecht, H. J. \& Deelstra, H. A. (1984). Dietary selenium intake in Belgium. Zeitschrift für LebensmittelUntersuchung und-Forschung 178, 266-271.

Robberecht, H. J., Hendrix, P., van Cauwenbergh, R. \& Deelstra, H. A. (1994a). Actual daily dietary intake of selenium in Belgium, using duplicate portion sampling. Zeitschrift für Lebensmittel-Untersuchung und -Forschung 199, 251-254.

Robberecht, H. J., Hendrix, P., van Cauwenbergh, R. \& Deelstra, H. A. (1994b). Daily dietary manganese intake in Belgium, using duplicate portion sampling. Zeitschrift für Lebensmittel-Untersuchung und-Forschung 199 , 446-448.

Roekens, E. J., Robberecht, H. J. \& Deelstra, H. A. (1986). Dietary selenium intake in Belgium for different population groups at risk for deficiency. Zeitschrift für Lebensmittel-Untersuchung und-Forschung 182, 8-13.

Roekens, E., Robberecht, H., Van Caillie-Bertrand, M., Deelstra, H. \& Clara, R. (1985). Daily intake of selenium by bottle-fed infants in Belgium. European Journal of Pediatrics 144, 45-48.

Scaccini, C., Sette, S., Mariotti, S., Verdecchia, A. \& Ferro-Luzzi, A. (1992). Nutrient adequacy of dietary intakes of elderly. Age and Nutrition 3, 41-47.

Schlettwein-Gsell, D., Dirren, H., Decarli, B., Barclay, D., Brubacher, G., Haller, J. \& Stähelin, H. B. (1991). Diet and nutritional status of $36170-75$ year old elderly in three regions of Switzerland. Third Swiss Nutrition Report, pp. 255-279. Bern: Federal Public Health Office.

Schuhmacher, M., Bosque, M. A., Domingo, J. L. \& Corbella, J. (1991). Dietary intake of lead and cadmium from foods in Tarragona Province, Spain. Bulletin of Environmental Contamination and Toxicology 46, 320-328.

Schuhmacher, M., Domingo, J. L., Llobet, J. M. \& Corbella, J. (1993). Dietary intake of copper, chromium and zinc in Tarragona Province, Spain. Science of the Total Environment 132, 3-10.

Schütz, A. (1979a). Cadmium and lead. Scandinavian Journal of Gastroenterology 14, Suppl. 52, $223-231$.

Schütz, A. (1979b). Mercury. Scandinavian Journal of Gastroenterology 14, Suppl. 52, 232-236.

Seidel, S. (1992). [Dietary Behaviour of School Children]. Dissertation, University of Giessen.

Stobbaerts, R., Robberecht, H. \& Deelstra, H. A. (1995). Daily dietary intake of manganese in several population groups in Belgium. Journal of Trace Elements in Medicine and Biology 9, 40-44.

Stobbaerts, R., Van Dael, P. \& Deelstra, H. (1991). Daily dietary intake of manganese in Belgium by different population groups. In Strategies for Food Quality Control and Analytical Methods in Europe (Proceedings of the 6th European Conference on Food Chemistry, Hamburg), vol. 2, pp. 881-884 [W. Baltes, T. Eklund, R. Fenwick, W. Pfannhauser, A. Ruiter and H. P. Thier, editors]. Frankfurt: Lebensmittelchemische Gesellschaft.

Strain, J. J., Barker, M. E., Livingstone, M. B. E. \& McKenna, P. G. (1990a). The Northern Ireland dietary survey and related studies. Proceedings of the Nutrition Society 49, 289-296.

Strain, J. J. \& Thompson, K. A. (1991). Biochemical indicators of iron status and dietary intakes of adults in Northern Ireland. In Trace Elements in Man and Animals-TEMA 7. Chapter 6, pp. 1-2 [B. Momčilović, editor]. Zagreb: University of Zagreb.

Strain, J. J., Thompson, K. A., Barker, M. E. \& Carville, D. G. M. (1990b). Iron sufficiency in the population of Northern Ireland: estimates from blood measurements. British Journal of Nutrition 64, 219-224.

Swerts, J., Benemariya, H., Robberecht, H., Van Cauwenbergh, R. \& Deelstra, H. (1993). Daily dietary intake of copper and zinc by several population groups in Belgium: preliminary reports. Journal of Trace Elements and Electrolytes in Health and Disease 7, 165-169.

Urieta, I., Jalón, M. \& Eguileor, I. (1995). Food surveillance in the Basque country (Spain). II. Estimation of the dietary intake of organochlorine pesticides, heavy metals, arsenic, aflatoxin $\mathbf{M}_{\mathbf{3}}$, iron and zinc through the Total Diet Study, 1990/91. Food Additives and Contaminants (In the Press). 
Vahter, M., Berglund, M., Friberg, L., Lind, B., Åkesson, A., Jorhem, L. \& Slorach, S. (1990). Dietary intake of lead and cadmium in Sweden. Vår Föda 44, Supplement 2 (16 pp.).

van Cauwenbergh, R., Hendrix, P., Robberecht, H. \& Deelstra, H. A. (1995). Daily dietary copper intake in Belgium, using duplicate portion sampling. Zeitschrift für Lebensmittel-Untersuchung und-Forschung 200, (In the Press).

van Dokkum, W., Schneijder, P., van Erp-Baart, A. M. J., van Aken, A. M. M. A. M., Muys, Th. \& van Schaik, F. (1994). Dietary intake in the Netherlands. Input from TNO Total Diet Study 1988-1989. 2. Minerals, trace elements and vitamins. TNO Report no. V 94.173. Zeist: TNO-Nutrition and Food Research.

Varela, G. (1981). [Recommended intakes of energy and nutrients for the Spanish people.] Madrid: Instituto de Nutrición, Consejo Superior de Investigaciones Científicas.

Zimmerli, B., Bosshard, R. \& Knutti, R. (1991). Non-essential toxic trace elements. Third Swiss Nutrition Report, pp. 149-162. Bern: Federal Public Health Office.

The data for this review have been submitted by the following persons:

H. Deelstra, University of Antwerp, Belgium;

S. Hø̈jbjerg, M. Hansen and B. Sandström, The Royal Veterinary and Agricultural University, Copenhagen, Denmark:

M. Lamand, INRA, Saint-Genès-Champanelle, France;

U. Schlemmer, Federal Research Centre for Nutrition, Karlsruhe, Germany;

S. Lee, D. Buss and H. M. Crews, Ministry of Agriculture, Fisheries and Food, Norwich, United Kingdom;

K. Cashman and A. Flynn, University College Cork, Republic of Ireland;

A. Ferro-Luzzi and G. Maiani, National Institute of Nutrition, Rome, Italy;

L. F. Andersen, University of Oslo, Norway;

R. Farré, University of Valencia, Spain;

D. Barclay, Nestlé Research Centre, Vevey, Switzerland. 